\title{
Efficient Direct Nitrosylation of $\alpha$-Diimine Rhenium Tricarbonyl Complexes to Structurally Nearly Identical Higher Charge Congeners Activable towards Photo-CO Release
}

\author{
Sara Nasiri Sovari ${ }^{1, \dagger}$, Isabelle Kolly ${ }^{1, \dagger}$, Kevin Schindler $^{1}{ }^{1}$, , Youri Cortat ${ }^{1}$, Shing-Chi Liu ${ }^{1}$, Aurelien Crochet ${ }^{1} \mathbb{D}_{\text {, }}$ \\ Aleksandar Pavic ${ }^{2}$ and Fabio Zobi ${ }^{1, *(\mathbb{D}}$ \\ 1 Department of Chemistry, Fribourg University, Chemin Du Musée 9, 1700 Fribourg, Switzerland; \\ sara.nasirisovari@unifr.ch (S.N.S.); isabelle.kolly@unifr.ch (I.K.); kevin.schindler@unifr.ch (K.S.); \\ youri.cortat@unifr.ch (Y.C.); shing-chi.liu@unifr.ch (S.-C.L.); aurelien.crochet@unifr.ch (A.C.) \\ 2 Institute of Molecular Genetics and Genetic Engineering, University of Belgrade, Vojvode Stepe 444a, \\ 11042 Belgrade, Serbia; sasapavic@imgge.bg.ac.rs \\ * Correspondence: fabio.zobi@unifr.ch \\ + These authors contributed equally to this paper.
}

\section{check for} updates

Citation: Nasiri Sovari, S.; Kolly, I.; Schindler, K.; Cortat, Y.; Liu, S.-C.; Crochet, A.; Pavic, A.; Zobi, F. Efficient Direct Nitrosylation of $\alpha$-Diimine Rhenium Tricarbonyl Complexes to Structurally Nearly Identical Higher Charge Congeners Activable towards Photo-CO Release. Molecules 2021, 26, 5302. https:// doi.org/10.3390/molecules26175302

Academic Editor: Michel Pfeffer

Received: 20 July 2021

Accepted: 28 August 2021

Published: 31 August 2021

Publisher's Note: MDPI stays neutral with regard to jurisdictional claims in published maps and institutional affiliations.

Copyright: (c) 2021 by the authors. Licensee MDPI, Basel, Switzerland. This article is an open access article distributed under the terms and conditions of the Creative Commons Attribution (CC BY) license (https:// creativecommons.org/licenses/by/ $4.0 /)$.

\begin{abstract}
The reaction of rhenium $\alpha$-diimine (N-N) tricarbonyl complexes with nitrosonium tetrafluoroborate yields the corresponding dicarbonyl-nitrosyl $\left[\operatorname{Re}(\mathrm{CO})_{2}(\mathrm{NO})(\mathrm{N}-\mathrm{N}) \mathrm{X}\right]^{+}$species (where $\mathrm{X}=$ halide). The complexes, accessible in a single step in good yield, are structurally nearly identical higher charge congeners of the tricarbonyl molecules. Substitution chemistry aimed at the realization of equivalent dicationic species (intended for applications as potential antimicrobial agents), revealed that the reactivity of metal ion in $\left[\operatorname{Re}(\mathrm{CO})_{2}(\mathrm{NO})(\mathrm{N}-\mathrm{N}) \mathrm{X}\right]^{+}$is that of a hard Re acid, probably due to the stronger $\pi$-acceptor properties of $\mathrm{NO}^{+}$as compared to those of $\mathrm{CO}$. The metal ion thus shows great affinity for $\pi$-basic ligands, which are consequently difficult to replace by, e.g., $\sigma$-donor or weak $\pi$-acids like pyridine. Attempts of direct nitrosylation of $\alpha$-diimine $f a c-\left[\operatorname{Re}(\mathrm{CO})_{3}\right]^{+}$complexes bearing $\pi$-basic OR-type ligands gave the $\left[\operatorname{Re}(\mathrm{CO})_{2}(\mathrm{NO})(\mathrm{N}-\mathrm{N})\left(\mathrm{BF}_{4}\right)\right]\left[\mathrm{BF}_{4}\right]$ salt as the only product in good yield, featuring a stable Re-FBF 3 bond. The solid state crystal structure of nearly all molecules presented could be elucidated. A fundamental consequence of the chemistry of $\left[\operatorname{Re}(\mathrm{CO})_{2}(\mathrm{NO})(\mathrm{N}-\mathrm{N}) \mathrm{X}\right]^{+}$ complexes, it that the same can be photo-activated towards $\mathrm{CO}$ release and represent an entirely new class of photoCORMs.
\end{abstract}

Keywords: rhenium; dicarbonyl; nitrosyl; photoCORM

\section{Introduction}

The growing trend of antimicrobial resistance (AMR) poses a serious threat to the public's health, making it more and more difficult to prevent and treat related diseases. Thousands of deaths have been attributed to AMR infections according to WHO findings published in 2018 [1], with an estimated death toll of millions of cases per year by 2050 if the appropriate measures are not taken [2]. With the increasing difficulty of major pharmaceutical companies to meet the demand of new antibiotics discovery and production, universities are contributing to the finding of new classes of active compounds. Pathogens, however, are likely to adapt rapidly and become resistant to new drugs if conventional medicinal chemistry approaches remain based exclusively on organic molecules, also in light of the fact that the majority of drugs in clinical development are modified versions of already-approved antibiotics [3].

There is an increasing awareness in academia of the potential of metal complexes to act as the new class of molecules for the purpose. Indeed, the unique chemistry and larger variety of $3 \mathrm{D}$ geometries of metal compounds can address targets and modes of action unavailable to organic molecules. In the last decade, complexes of virtually all transition 
metals have been evaluated [3,4], with rhenium, among others [5,6], showing promising potential for new antibiotic development [7-10].

Our group has been interested in the development of the chemistry of tri- and dicarbonyl rhenium complexes for applications in different medicinal fields [11-18], including their use as antibacterial agents. We recently reported studies on the antimicrobial properties of families of rhenium diimine $(\mathrm{N}-\mathrm{N})$ complexes and found several complexes of general formula $f a c-\left[\operatorname{Re}^{\mathrm{I}}(\mathrm{CO})_{3}(\mathrm{~N}-\mathrm{N}) \mathrm{L}\right]^{+}(\mathrm{L}=$ pyridine, py, type-ligand), showing low to no toxicity in vivo and potent in vitro and in vivo activity against infection of clinically relevant bacteria (MRSA) and fungi (Candida species) [19,20]. Unlike similar complexes tested against cancers, where the overall charge of the compound does not seem to be a critical factor, a survey of the literature and our own data [20] indicates that positively charged rhenium complexes are most effective against the microbes. The mechanism of action of these agents remains largely unknown, but we hypothesize that the positive charge of the complexes is important for their interaction with phosphatidylglycerol and cardiolipin anionic lipids. All bacterial membranes contain at least $15 \%$ anionic lipid. Exposure to these lipids confers selectivity to cationic antimicrobial agents for toxicity against bacteria but not against mammalian cells [21,22]. Among the steps involved in the mechanism of action of the highly effective trimetallic complexes of Metzler-Nolte and Bandow, e.g., is the targeting of the cytoplasmic membrane, where the complexes affect membrane architecture and disrupt essential cellular functions, such as respiration and cell wall formation and integrity [7].

Given the data currently available on rhenium species, it is possible that by increasing the overall complex charge and by modulating molecules' lipophylicity, binding to fungal and bacterial cell walls, cell membrane (and/or intracellular) accumulation might be enhanced, thereby potentially enhancing the overall antimicrobial efficacy of this class of molecules. To test this hypothesis, the new species should be structurally very close (if not identical) to the active $f a c-\left[\operatorname{Re}^{\mathrm{I}}(\mathrm{CO})_{3}(\mathrm{~N}-\mathrm{N}) \mathrm{L}\right]^{+}$complexes, but with a higher charge. Charge modulation may be archived by the appropriate choice of a cationic $\mathrm{N}-\mathrm{N}$ derivative or the monodentate ligand $\mathrm{L}$ in the drug sphere of the complexes [23], or by chemically modifying the $f a c-\left[\operatorname{Re}^{\mathrm{I}}(\mathrm{CO})_{3}\right]^{+}$core. The latter possibility is more challenging, but there are options. In particular our attention turned to the equivalent $f a c-\left[\operatorname{Re}^{\mathrm{I}}(\mathrm{CO})_{2}(\mathrm{NO})\right]^{2+}$ core [24-26].

A compound of formula fac- $\left[\operatorname{Re}^{\mathrm{I}}(\mathrm{CO})_{2}(\mathrm{NO})(\mathrm{bpy}) \mathrm{Cl}\right]^{+}$(where $f a c$ refers here to the arrangement of the $\mathrm{CO}$ and $\mathrm{NO}$ ligands) was prepared previously by the groups of Alberto and Berke via a multi-step synthesis from cubic $\mu$-oxo bridged teranuclear $\left[\operatorname{Re}\left(\mu_{3}-\right.\right.$ $\left.\mathrm{O})(\mathrm{CO})_{2}(\mathrm{NO})\right]_{4}$ clusters [27] and, under inert conditions, from the $\left[\operatorname{ReCl}(\mu-\mathrm{Cl})(\mathrm{CO})_{2}(\mathrm{NO})\right]_{2}$ dimer respectively (Scheme 1) [28]. Nothing is known about the chemistry of the compound or if the same could be used as a synthon for $f a c-\left[\operatorname{Re}^{\mathrm{I}}(\mathrm{CO})_{2}(\mathrm{NO})(\mathrm{N}-\mathrm{N}) \mathrm{L}\right]^{2+}$ species. We, therefore, set out to first establish a convenient synthetic procedure to $f a c-\left[\operatorname{Re}^{\mathrm{I}}(\mathrm{CO})_{2}(\mathrm{NO})(\mathrm{N}\right.$ $\mathrm{N}) \mathrm{XJ}^{+}$complexes (where $\mathrm{X}=$ halide) and then to study their substitution chemistry aiming at the realization of the dicationic species just mentioned above.

In this contribution, we describe our synthetic efforts, and we present an efficient direct nitrosylation of $\alpha$-diimine rhenium tricarbonyl complexes widely applicable to different supporting N-N ligands. The resulting compounds are structurally nearly identical higher charge congeners of tricarbonyls. We found that, while similar complexes are reported as rhenium(I) dicarbonyl-nitrosyl species [24-28], the substitution chemistry of metal ion in $f a c-\left[\operatorname{Re}(\mathrm{CO})_{2}(\mathrm{NO})(\mathrm{N}-\mathrm{N}) \mathrm{X}\right]^{+}$is that of a hard Re acid, probably due to the stronger $\pi$ acceptor properties of $\mathrm{NO}^{+}$as compared to those of $\mathrm{CO}$. A fundamental consequence of this behavior is that $f a c-\left[\operatorname{Re}(\mathrm{CO})_{2}(\mathrm{NO})(\mathrm{N}-\mathrm{N}) \mathrm{X}\right]^{+}$complexes can be photo-activated towards $\mathrm{CO}$ release and represent an entirely new class of photoCORMs. 


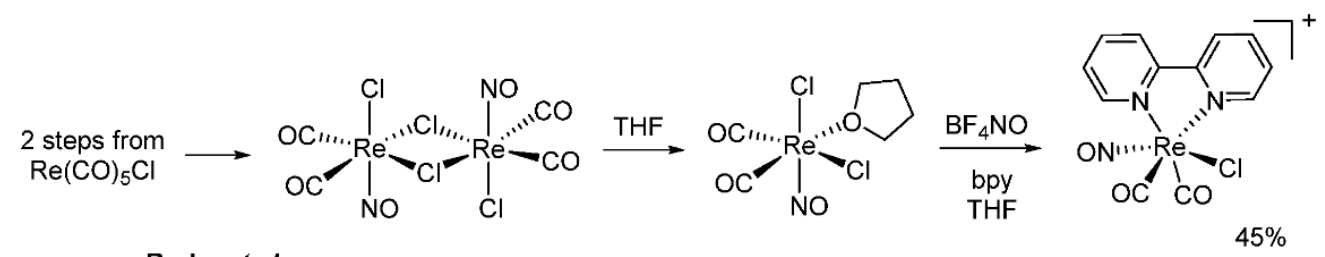

Berke et al.

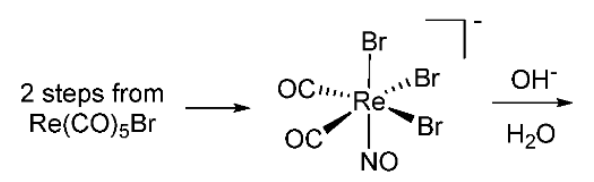

Alberto et al.

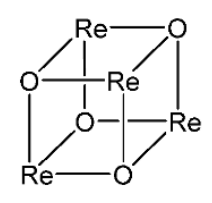

$\operatorname{Re}=\operatorname{Re}(\mathrm{CO})_{3}$
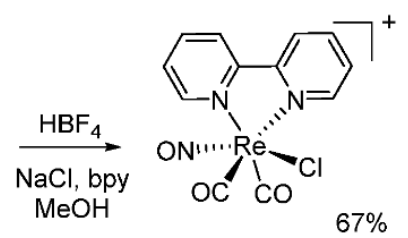

$67 \%$

Scheme 1. Known synthetic procedures to $f a c-\left[\operatorname{Re}^{\mathrm{I}}(\mathrm{CO})_{2}(\mathrm{NO})(\mathrm{N}-\mathrm{N})(\mathrm{X})\right]^{+}$type-complexes. The \% yields refer to those of the last step only.

\section{Results}

\subsection{Synthesis of fac- $\left[\operatorname{Re}(\mathrm{CO})_{2}(\mathrm{NO})(\mathrm{N}-\mathrm{N}) \mathrm{X}\right]^{+}$Species}

The chemistry of the $f a c-\left[\operatorname{Re}(\mathrm{CO})_{2}(\mathrm{NO})\right]^{2+}$ core is essentially dominated by cyclopentadienyl $(\mathrm{Cp})$ species of general formula $\left[\mathrm{CpRe}(\mathrm{CO})_{2}(\mathrm{NO})\right]^{+}$. These compounds are most often prepared by reaction of the corresponding [CpRe(CO) 3 ] with either $\mathrm{NO}_{2} \mathrm{PF}_{6}$ [29], $\mathrm{NOHSO}_{4}$ [30], or $\mathrm{NOBF}_{4}[31,32]$. The last two reagents were successfully used in the preparation of $f a c-\left[\operatorname{Re}^{\mathrm{I}}(\mathrm{CO})_{2}(\mathrm{NO}) \mathrm{X}_{3}\right]^{-}[24,27]$, and of the two, the latter appeared to us the most convenient as the procedure involves simple addition of the nitrosonium tetrafluoroborate salt in a $\mathrm{CH}_{2} \mathrm{Cl}_{2}$ (DCM) solution of the rhenium tricarbonyl complex [32]. The reaction has also the advantage of producing an ion pair from the initially introduced components with, theoretically, no side products.

Thus, we first attempted a reaction of $f a c-\left[\operatorname{Re}^{\mathrm{I}}(\mathrm{CO})_{3}(\mathrm{bpy}) \mathrm{Br}\right]$ with an excess (2.5-5 eq.) of $\mathrm{NOBF}_{4}$ in DCM. During the course of the reaction, the colour of the solution changed from a dark to a pale yellow and the same lost its photoluminescence properties. The corresponding dicarbonyl-nitrosyl $\mathrm{fac}-\left[\operatorname{Re}(\mathrm{CO})_{2}(\mathrm{NO})(\mathrm{bpy}) \mathrm{Br}\right]^{+}$species (1) was isolated as a $\mathrm{BF}_{4}{ }^{-}$salt in $70 \%$ yield (Figure 1), following crystallization by vapor diffusion with pentane or by slow evaporation of DMC, after excess $\mathrm{NOBF}_{4}$ was filtered off. In its crystalline form, $\mathbf{1}$ is slightly hygroscopic, and it decomposes if purification is attempted on a solid phase (silica or alumina). The same reaction was also attempted with phenanthroline (phen) and $4,4^{\prime}$ - or 4,7- derivatives of bpy and phen, respectively, giving similar results (complexes $2-5$, Figure 1, in 60-70\% yield). In comparison to the synthetic procedures of Alberto and Berke, our route appears straightforward, overall higher yielding and generally applicable to widely accessible $\alpha$-diimine $f a c-\left[\operatorname{Re}^{\mathrm{I}}(\mathrm{CO})_{3}\right]^{+}$species.

\subsection{Spectroscopic Properties of fac- $\left[\operatorname{Re}(\mathrm{CO})_{2}(\mathrm{NO})(\mathrm{N}-\mathrm{N}) \mathrm{X}\right]^{+}$Species}

The physical properties of the $f a c-\left[\operatorname{Re}(\mathrm{CO})_{2}(\mathrm{NO})\right]^{2+}$ complexes prepared in this study are summarized in Table 1 . The IR spectra of the compounds show the pattern expected for the dicarbonyl-nitrosyl species. Consistent with what reported before, the $\mathrm{CO}$ stretching $\left(\nu \mathrm{CO}\right.$ 's) frequencies of $f a c-\left[\operatorname{Re}(\mathrm{CO})_{2}(\mathrm{NO})(\mathrm{N}-\mathrm{N}) \mathrm{Br}\right]^{+}$complexes $\mathbf{1}-\mathbf{5}$ are substantially shifted to higher wavenumbers, which is unusual for carbonyls bound to the low valent metal [33,34]. In fact, the $v C \mathrm{CO}^{\prime} \mathrm{s}$ are found in the region where rhenium(III) dicarbonyl complexes [35] (e.g., $\left.\left[\operatorname{Re}^{\mathrm{III}}(\mathrm{CO})_{2} \mathrm{Br}_{4}\right]^{-}\right)[36]$ are observed, and much higher than corresponding rhenium(II) species [37]. The symmetric $v \mathrm{CO}$ mode of the molecules is actually not far from that of $\mathrm{CO}$ gas $\left(2143 \mathrm{~cm}^{-1}\right)$. The evidence points to a significant reduction of Re-CO $\pi$-backbonding in favour of the stronger $\pi$-acceptor $\mathrm{NO}^{+}$. The stretching vibration of the $\mathrm{NO}^{+}$ion usually occurs in the $2300-2350 \mathrm{~cm}^{-1}$ frequency range, e.g., $2340 \mathrm{~cm}^{-1}$ in $\mathrm{NOBF}_{4}$ [38], $2326 \mathrm{~cm}^{-1}$ in $\mathrm{NOAuF}_{6}$ [39], and $2298 \mathrm{~cm}^{-1}$ in sulfuric acid solutions [40]. Its vibrational frequency in the complexes is found in the $1800 \mathrm{~cm}^{-1}$ region, closer to that of a $\mathrm{N}=\mathrm{O}$ double bond 
than that of the initial triple bond. This indicates that the $\pi^{*} \mathrm{p}(\mathrm{NO})$-orbitals accept electron density to a great degree, depleting the metal ion of the same. Theoretically, a $\mathrm{N}=\mathrm{O}$ double implies full occupation of a $\pi^{*} p(\mathrm{NO})$-orbital, which would formally result in a metal center of higher oxidation state. Indeed, this formalism could account for the reactivity of the species (vide infra) and their lack of photoluminescence (see Supplementary Materials).

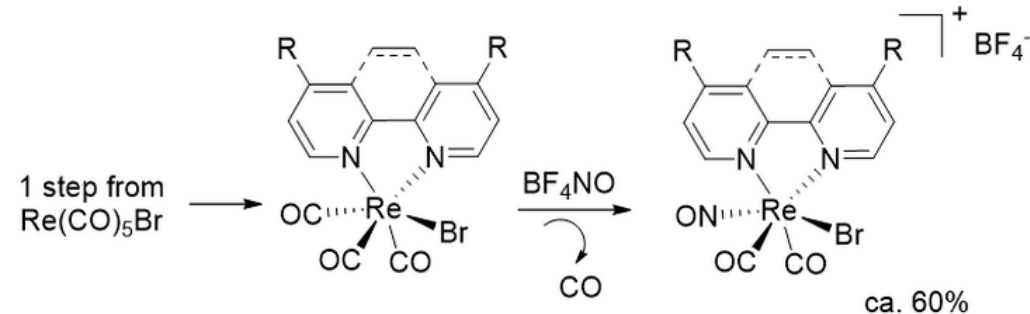

$\mathrm{R}=\mathrm{H}(\mathbf{1}), \mathrm{NEt}_{2}(\mathbf{3}),{ }^{\mathrm{t}} \mathrm{Bu}(\mathbf{4})$ for bpy ligand $R=H(2)$, phenyl (5) for phen ligand
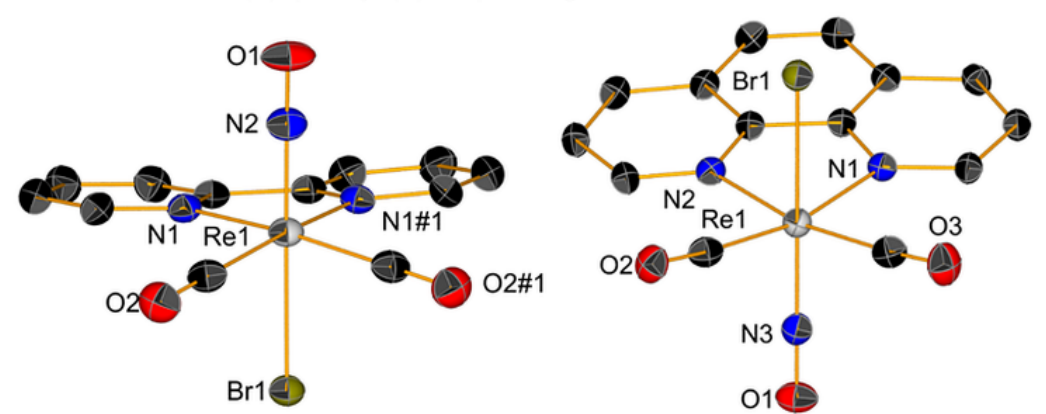

Figure 1. General synthetic approach to $f a c-\left[\operatorname{Re}(\mathrm{CO})_{2}(\mathrm{NO})(\mathrm{N}-\mathrm{N}) \mathrm{Br}\right]^{+}$complexes 1-5 (top) and crystal structures of compounds $\mathbf{1}$ (left) and 2. Thermal ellipsoids are at 30\% probability. Hydrogen atoms and $\mathrm{BF}_{4}{ }^{-}$counter ion omitted for clarity. Selected bond lengths $(\AA): 1, \operatorname{Re}-\mathrm{N} 1$ 2.140(4), Re-N2 1.782(6), Re-Br 2.5372(7), Re-CO 1.990(5), C-O 1.123(6), N-O 1.164(7); 2, Re-N1 2.154(3), Re-N2 2.153(3), ReN3 1.801(4), Re-Br 2.5425(5), Re-CO 2.002(4) and 2.009(4), C-O 1.118(5) and 1.120(5), N-O 1.143(5). Selected bond angles $\left({ }^{\circ}\right)$ : 1, O1-N2-Re1 175.3(6); 2, O1-N3-Re1 178.4(3).

Table 1. Physical properties of $f a c-\left[\operatorname{Re}^{\mathrm{I}}(\mathrm{CO})_{2}(\mathrm{NO})(\mathrm{N}-\mathrm{N}) \mathrm{X}\right]^{+}$complexes.

\begin{tabular}{cccc}
\hline Complex & $\boldsymbol{v ( C O )}\left[\mathbf{c m}^{-\mathbf{1}}\right]^{\mathbf{a}}$ & $v(\mathbf{N O})\left[\mathbf{c m}^{-\mathbf{1}}\right]^{\mathbf{a}}$ & $\left.\lambda_{\max }\left[\mathbf{n m} \mathbf{M}^{-\mathbf{1}} \mathbf{c m}^{-\mathbf{1}}\right)\right]^{\mathbf{b}}$ \\
\hline $\mathbf{1}$ & 2112,2050 & 1801 & 312,321 \\
\hline $\mathbf{2}$ & 2118,2057 & 1790 & $304,339,375$ \\
\hline $\mathbf{3}$ & 2104,2040 & 1770 & 342,357 \\
\hline $\mathbf{4}$ & 2114,2053 & 1797 & 309,318 \\
\hline $\mathbf{5}$ & 2114,2052 & 1795 & $297,336,375$ \\
\hline $\mathbf{6}$ & 2113,2051 & 1779 & 307,316 \\
\hline $\mathbf{7}$ & 2106,2033 & 1784 & 342,352 \\
\hline $\mathbf{1 2}$ & 2127,2069 & 1820 & 320,330 \\
\hline $\mathbf{1 4}$ & 2114,2050 & 1796 & 323,332 \\
\hline
\end{tabular}

a Solid state pure product. ${ }^{\mathrm{b}}$ in DMF.

The UV-Vis spectra of the compounds are characterized by a main absorption with two closely spaced maxima in 300-340 $\mathrm{nm}$ region (Table 1 and Supplementary Materials). Only complexes $\mathbf{2}$ and $\mathbf{5}$ (phenanthroline derivatives) show a single relatively broad peak for the same absorption, with two additional lower-lying small peaks at 340 and $375 \mathrm{~nm}$, respectively. We did not perform a TDDFT analysis, but we suggest that the high-energy transitions are likely associated with $\pi \rightarrow \pi^{*}$ intra-ligand transitions attributed to the 
diimine-system. In solution, all dicarbonyl-nitrosyl species show sharp signals in their NMR spectra, consistent with the diamagnetic nature of the molecules. With respect to the corresponding tricarbonyl complexes, $f a c-\left[\operatorname{Re}(\mathrm{CO})_{2}(\mathrm{NO})(\mathrm{N}-\mathrm{N}) \mathrm{X}\right]^{+}$show consistently a downfield shift of the N-N signals (Figure 2 and Supplementary Materials). This evidence further supports the assignment of a higher oxidation state of the Re atom.

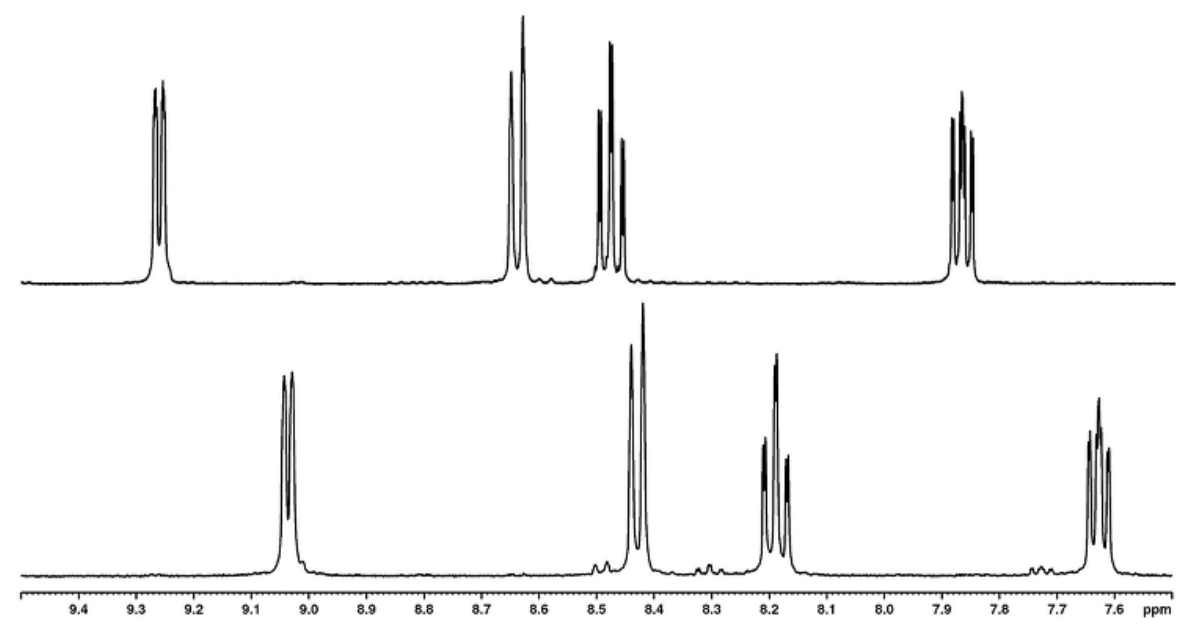

Figure 2. Aromatic regions of the ${ }^{1} \mathrm{H}-\mathrm{NMR}$ spectra of $f a c-\left[\operatorname{Re}(\mathrm{CO})_{2}(\mathrm{NO})(\mathrm{bpy}) \mathrm{Br}\right]^{+}(\mathbf{1}$, top $)$ and fac- $\left[\operatorname{Re}^{\mathrm{I}}(\mathrm{CO})_{3}(\mathrm{bpy}) \mathrm{Br}\right]^{+}$. Both spectra recorded in $\mathrm{CD}_{3} \mathrm{CN}$.

\subsection{Attempted Synthesis of fac-[Re(CO) $\left.)_{2}(\mathrm{NO})(\mathrm{N}-\mathrm{N}) \mathrm{L}\right]^{2+}$ Species}

Having established a sufficiently high-yielding procedure for $f a c-\left[\operatorname{Re}(\mathrm{CO})_{2}(\mathrm{NO})(\mathrm{N}-\right.$ $\mathrm{N}) \mathrm{Br}]^{+}$ions, we moved to explore the substitution of $\mathrm{Br}^{-}$for neutral pyridine (py) ligands. Typically, for the corresponding tricarbonyl complexes, bromide replacement is achieved either by treatment with trifluoromethanesulfonic acid or by addition of a silver salt. We first monitored by ${ }^{1} \mathrm{H}-\mathrm{NMR}$ the addition of $\mathrm{AgCF}_{3} \mathrm{SO}_{3}$ to $\mathrm{fac}-\left[\mathrm{Re}(\mathrm{CO})_{2}(\mathrm{NO})(\mathrm{bpy}) \mathrm{Br}\right]^{+}(\mathbf{1})$ in coordinating wet solvents like $\mathrm{CH}_{3} \mathrm{OH}$ or $\mathrm{CH}_{3} \mathrm{CN}$. The spectrum revealed no change in the frequency of the proton signals over a period of 3 days. In a parallel reaction, the same conditions were used, but pyridine was added to the mixture. Overnight, new signals appeared in the NMR spectrum, but the set of frequencies attributable to free py remained unchanged. We initially hypothesized that the hydroxide $f a c-\left[\operatorname{Re}(\mathrm{CO})_{2}(\mathrm{NO})(\mathrm{bpy})(\mathrm{OH})\right]^{+}$ had formed, but later found that py, as a base, promoted $\mathrm{BF}_{4}{ }^{-}$hydrolysis to $\left[\mathrm{BF}_{3}(\mathrm{OH})\right]^{-}$ and $\mathrm{F}^{-}[41]$, and the latter substituted $\mathrm{Br}^{-}$to give $f a c-\left[\operatorname{Re}(\mathrm{CO})_{2}(\mathrm{NO})(\mathrm{bpy}) \mathrm{F}\right]^{+}(6$, Figure 3$)$. As mentioned above, this type of reactivity of the metal ion is consistent with a hard Re acid and fully congruous with the spectroscopic data discussed above.

The higher apparent formal oxidation state of the metal ion implies the depletion of electron density from the same, and affinity for $\pi$-basic ligands rater $\sigma$-donors. We reasoned, therefore, that electron-donating substituents on N-N might help stabilize the rhenium ion towards the same reaction. $\mathrm{NR}_{2}$ groups (where $\mathrm{R}=$ aliphatic chain) are amongst the most effective electron donating groups [42]. However, when the $N^{4}, N^{4}, N^{4^{\prime}}, N^{4^{\prime}}$. tetraethyl-[2,2'-bipyridine]-4,4'-diamine ( $\mathrm{Et}_{2} \mathrm{~N}$-bpy) complex 3 was used the corresponding fac- $\left[\operatorname{Re}^{\mathrm{I}}(\mathrm{CO})_{2}(\mathrm{NO})\left(\mathrm{Et}_{2} \mathrm{~N}-\mathrm{bpy}\right) \mathrm{F}\right]^{+}$(7) also formed as the only product. Compound (7) was isolated in $30 \%$ yield and was recrystallized from methanol. Its $X$-ray structure is also shown in Figure 3.

We recently published synthetic procedures to aerobically stable and substitutionally labile $\alpha$-diimine rhenium(I) dicarbonyl complexes of formula $\left[\operatorname{Re}^{\mathrm{I}}(\mathrm{CO})_{2}(\mathrm{~N}-\mathrm{N}) \operatorname{Br}(\mathrm{py})\right]$ capable of exchanging the halide for other ligands [37]. Therefore, we next tried the reaction of the corresponding $\left[\operatorname{Re}^{\mathrm{I}}(\mathrm{CO})_{2}(\mathrm{bpy}) \mathrm{Br}(\mathrm{py})\right]$ complex $(8)$ with $\mathrm{NOBF}_{4}$. Under reaction conditions similar to those applied for the synthesis of $1-5$, complex 8 reacted by substituting py for $\mathrm{NO}^{+}$giving 1 (Figure 4). We only found trace evidence in the MS spectrum of the desired $f a c-\left[\operatorname{Re}(\mathrm{CO})_{2}(\mathrm{NO})(\mathrm{bpy}) \mathrm{py}\right]^{2+}$ species. 


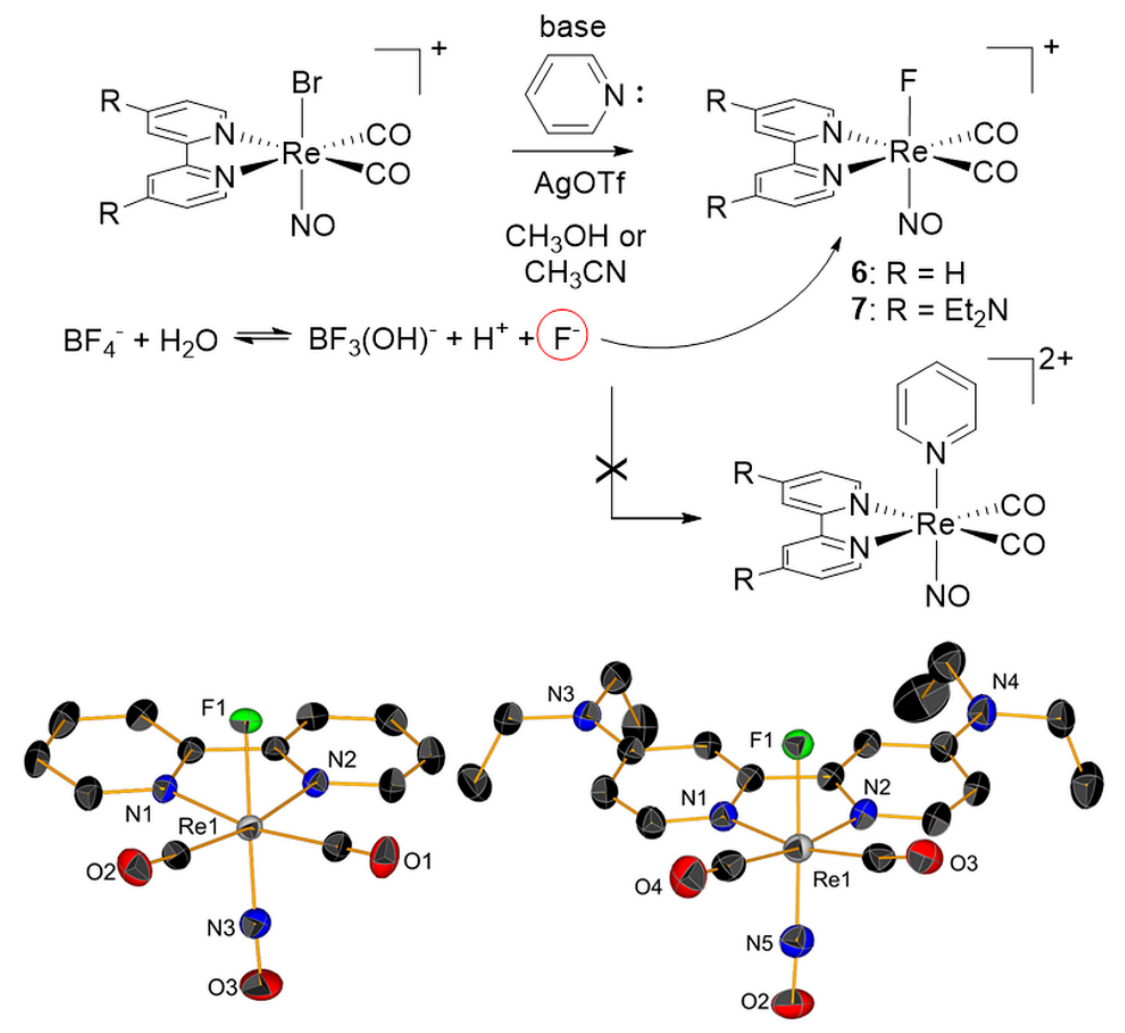

Figure 3. Reaction scheme of attempted synthesis fac- $\left[\operatorname{Re}(\mathrm{CO})_{2}(\mathrm{NO})(\mathrm{N}-\mathrm{N}) \mathrm{py}\right]^{2+}$ species from corresponding dicarbonyl-nitrosyl species in the presence of $\mathrm{Ag}^{+}$and py (top) and crystal structure of compound 6 (left) and 7. Thermal ellipsoids are at 30\% probability. Hydrogen atoms and $\mathrm{BF}_{4}{ }^{-}$ counter ion omitted for clarity. Selected bond lengths ( $\AA$ ): 6, Re-N1 2.138(4), Re-N2 2.145(4), Re-N3 1.773(6), Re-F 1.970(3), Re-CO 2.020(6) and 1.999(6), C-O 1.108(7) and 1.115(7), N-O 1.159(7); 7, Re-N1 2.121(3), Re-N2 2.123(4), Re-N5 1.763(4), Re-F 1.984(3), Re-CO 2.017(5) and 1.991(6), C-O 1.123(6) and 1.129(6), N-O 1.185(5). Selected bond angles ( $\left.{ }^{\circ}\right)$ : 6, O3-N3-Re1 177.3(6); 7, O2-N5-Re1 176.8(4).<smiles></smiles><smiles></smiles>

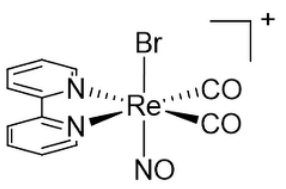

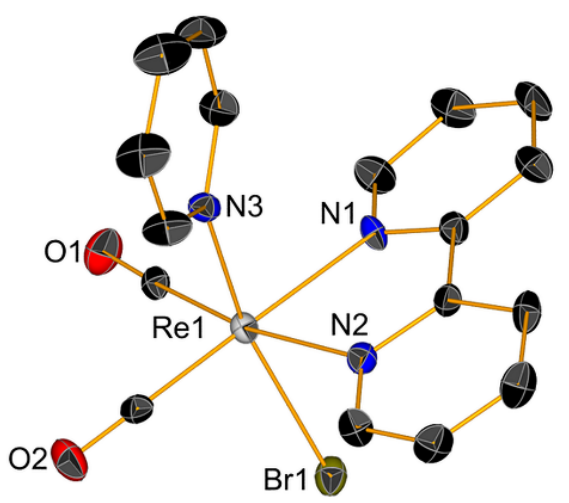

Figure 4. Reaction scheme of attempted synthesis $f a c-\left[\operatorname{Re}(\mathrm{CO})_{2}(\mathrm{NO})(\mathrm{N}-\mathrm{N}) \mathrm{py}\right]^{2+}$ species from corresponding $\left[\operatorname{Re}^{\mathrm{I}}(\mathrm{CO})_{2}(\mathrm{~N}-\mathrm{N})(\mathrm{py}) \mathrm{Br}\right]$ complex 8 and crystal structure of the same. Thermal ellipsoids are at $30 \%$ probability. Hydrogen atoms are omitted for clarity.

It should be noted here that Rattat reported that whereas the imidazole (Im) complexes $\left[\mathrm{ReCl}_{2}(\mathrm{Im})(\mathrm{CO})_{2}(\mathrm{NO})\right]$ and $\left[\operatorname{ReCl}(\mathrm{Im})_{2}(\mathrm{CO})_{2}(\mathrm{NO})\right]^{+}$can be synthesized in high yields from $\left[\mathrm{NEt}_{4}\right]\left[\mathrm{ReCl}_{3}(\mathrm{CO})_{2}(\mathrm{NO})\right]$ or $\left[\operatorname{ReCl}(\mu-\mathrm{Cl})(\mathrm{CO})_{2}(\mathrm{NO})\right]_{2}$, isolation of the $\left[\operatorname{Re}(\operatorname{Im})_{3}(\mathrm{CO})_{2}(\mathrm{NO})\right]^{2+}$ was not successful [43]. The authors argued that this is due to the behaviour of the fac$\left[\operatorname{Re}(\mathrm{CO})_{2}(\mathrm{NO})\right]^{2+}$ fragment in water (the reaction solvent), where the core initially binds three water molecules, one of which is deprotonated, and the resulting hydroxy group 
cannot be substituted by the $\sigma$-donor Im [44]. However, the trace evidence of the desired fac- $\left[\operatorname{Re}(\mathrm{CO})_{2}(\mathrm{NO})(\text { bpy)py }]^{2+}\right.$ species we detected by mass spectrometry, encouraged us to pursue our attempts.

Therefore, we probed directly the reactivity of $f a c-\left[\operatorname{Re}^{I}(C O)_{3}(N-N)(p y)\right]^{+}$complexes with nitrosonium tetrafluoroborate. Following the logic above, we probed the reaction of $f a c-\left[\operatorname{Re}(\mathrm{CO})_{3}\right]^{+}$complexes with combinations of bpy and $\mathrm{Et}_{2} \mathrm{~N}-\mathrm{bpy}$ (as N-N ligands) with py and $N, N$-dimethylpyridin-4-amine (Me $2 \mathrm{~N}$-py) $[45,46]$. What guided our choice, was again consideration that electron-donating substituents (EDS) on N-N or py might be needed to stabilize the rhenium ion in the particular ligand arrangement. We envisioned two cases as shown in Figure 5. In case A we considered the possibility of EDS on the bidentate $\mathrm{N}-\mathrm{N}$ ligand cis to NO, in case $\mathbf{B}$ EDS on the monodentate ligand trans to NO. As illustrated in Figure 5, we found no evidence of reaction with $\mathrm{NO}^{+}$when the fac- $\left[\operatorname{Re}^{\mathrm{I}}(\mathrm{CO})_{3}\left(\mathrm{Et}_{2} \mathrm{~N}-\mathrm{bpy}\right)(\mathrm{py})\right]^{+}$complex $\mathbf{A}$ was tested. However, complex $\mathbf{B}$ gave the corresponding $f a c-\left[\operatorname{Re}(\mathrm{CO})_{2}(\mathrm{NO})(\text { bpy })\left(\mathrm{Me}_{2} \mathrm{~N}-\mathrm{py}\right)\right]^{2+}(9)$ species as the kinetic, but not as the thermodynamically stable, product. The dicationic species could be isolated as it precipitated immediately from DCM following $\mathrm{CO}$ replacement by $\mathrm{NO}^{+}$. Evidence for the product came from both NMR and IR, which show, respectively, the expected downfield shift of all protons and the dicarbonyl-nitrosyl pattern (Supplementary Materials). The complex, however, is not pure and purification or crystallization attempts invariably lead to its decomposition.

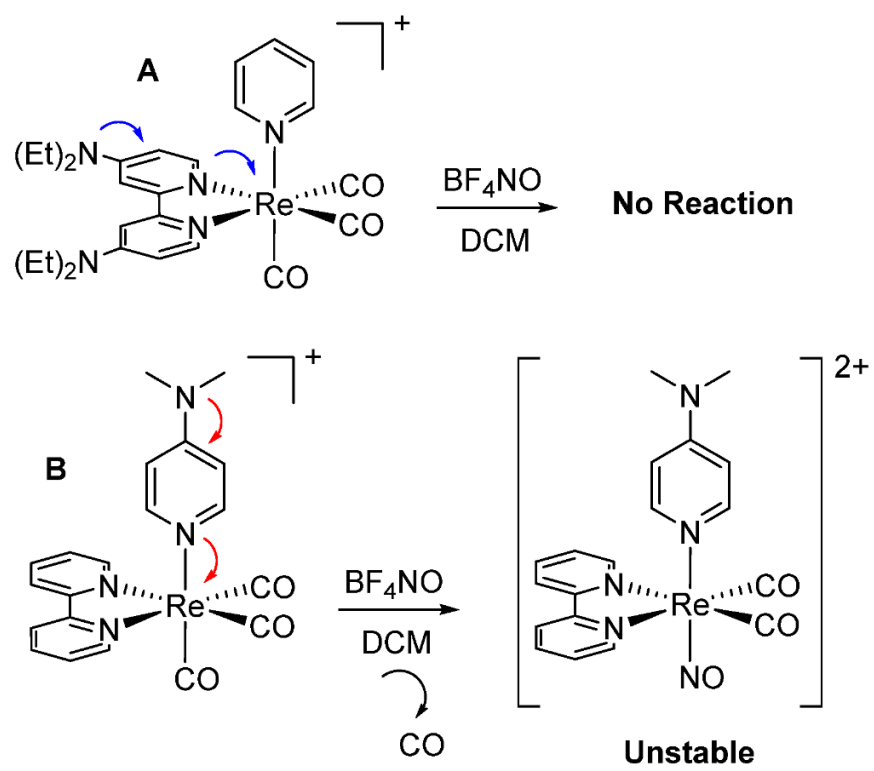

Figure 5. Molecular possibilities (A,B) envisioned to stabilize the $f a c-\left[\operatorname{Re}(\mathrm{CO})_{2}(\mathrm{NO})\right]^{2+}$ core via EDS on $\mathrm{N}-\mathrm{N}$ and monodentate py ligand and reactions of corresponding tricabonyl complexes with $\mathrm{NO}^{+}$.

\subsection{Reactivity of fac- $\left[\operatorname{Re}^{I}(C O)_{3}(N-N) O R\right]$ Species $\left(O R=\pi\right.$-Base) with $N^{+}$}

While studying the reactions above, and in order to better understand the chemistry of the $\mathrm{NO}^{+}$species, we also decided to explore nitrosylation of $f a c-\left[\operatorname{Re}^{\mathrm{I}}(\mathrm{CO})_{3}(\mathrm{~N}-\mathrm{N})\right]$ complexes with monodentate $\pi$-basic ligands (OR). Given the apparent affinity of the $f a c-\left[\operatorname{Re}(\mathrm{CO})_{2}(\mathrm{NO})\right]^{2+}$ core for $\pi$-donors, we reasoned that $f a c-\left[\operatorname{Re}^{\mathrm{I}}(\mathrm{CO})_{3}(\mathrm{~N}-\mathrm{N}) \mathrm{OR}\right]$ species might offer us a different chemical approach for the design of an efficient synthetic strategy to $f a c-\left[\operatorname{Re}(\mathrm{CO})_{2}(\mathrm{NO})(\mathrm{N}-\mathrm{N}) \mathrm{L}\right]^{2+}$ compounds. Therefore, we decided to test the reaction of fac- $\left[\operatorname{Re}^{\mathrm{I}}(\mathrm{CO})_{3}(\mathrm{~N}-\mathrm{N}) \mathrm{OR}\right]$, where $\mathrm{OR}=\mathrm{OH}^{-}$, benzoate (10), 2-(4-bromophenyl)acetate (11).

To our surprise, irrespective of the OR ligand, nitrosylation of $f a c-\left[\operatorname{Re}^{\mathrm{I}}(\mathrm{CO})_{3}(\mathrm{~N}-\mathrm{N}) \mathrm{OR}\right]$ gave always the same dicarbonyl-nitrosyl product (i.e., with the identical spectroscopic signature). In the case of OR = benzoate or 2-(4-bromophenyl)acetate, the NMR evidence clearly indicated that OR was no longer coordinated to the rhenium ion. However, it was initially difficult to reconcile the spectroscopic fingerprints of the product with those of the 
same obtained from the hydroxo complex (i.e., when $\mathrm{OR}=\mathrm{OH}^{-}$), also in light of the fact that we used dry solvents in the manipulations. The relatively high $v \mathrm{CO}$ frequencies of the product ( 2127 and $2069 \mathrm{~cm}^{-1}$ ) were also surprising and, on the basis of what we have shown before [33,34], they could not correspond to the electronic contribution of a coordinated $\mathrm{OH}^{-}$base. Kurz and Alberto showed that the reactivity $\mu$-oxo bridged teranuclear $\left[\operatorname{Re}\left(\mu_{3}-\right.\right.$ $\left.\mathrm{O})(\mathrm{CO})_{2}(\mathrm{NO})\right]_{4}$ clusters towards neutral bidentate ligands is possible by disassembly of the same in $\mathrm{HBF}_{4}$ and proceeds "presumably [via] Re-bound labile $\mathrm{BF}_{4}{ }^{-}$anion" [27]. We managed to crystallize the nitrosylated product obtained from $f a c-\left[\operatorname{Re}^{\mathrm{I}}(\mathrm{CO})_{3}(\mathrm{~N}-\mathrm{N}) \mathrm{OR}\right]$ and we confirmed that the reaction gives $f a c-\left[\operatorname{Re}(\mathrm{CO})_{2}(\mathrm{NO})(\mathrm{N}-\mathrm{N})\left(\mathrm{BF}_{4}\right)\right]\left[\mathrm{BF}_{4}\right](\mathbf{1 2})$ as the only product in good yield (Figure 6). To our knowledge, $\mathbf{1 2}$ is only the fourth structurally characterized Re--FBF 3 complex, and the very first one of its kind [47-49]. The Re- $\mathrm{FBF}_{3}$ bond is persistent in solution, and in $\mathrm{CH}_{3} \mathrm{CN}$ only a small fraction of the molecules (ca. 5-7\%) substitute the anion for $\mathrm{CH}_{3} \mathrm{CN}$. We were also able to selectively crystallize out the fac- $\left[\operatorname{Re}(\mathrm{CO})_{2}(\mathrm{NO})(\mathrm{N}-\mathrm{N})\left(\mathrm{CH}_{3} \mathrm{CN}\right)\right]^{2+}$ complex $(\mathbf{1 3})$ as a $\left[\mathrm{Na}\left(\mathrm{BF}_{4}\right)_{3}\right]^{2-}$ salt (Figure 6), but we did not study it further.
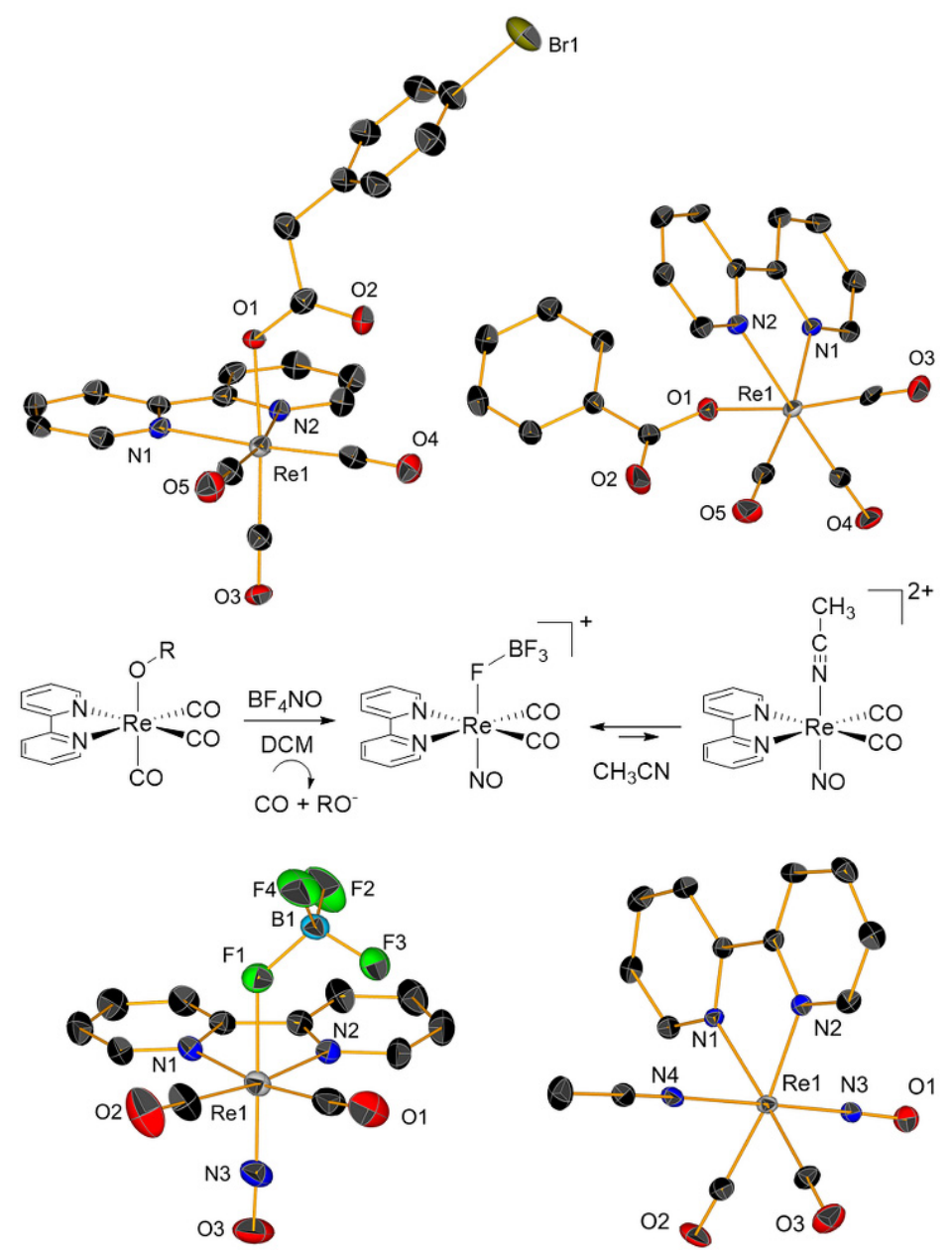

Figure 6. Top: crystal structures of carboxylato compounds $\mathbf{1 0}$ (left) and 11. Middle: scheme of the reaction of $f a c-\left[\operatorname{Re}^{\mathrm{I}}(\mathrm{CO})_{3}(\mathrm{~N}-\mathrm{N})(\mathrm{OR})\right]\left(\mathrm{OR}=\mathrm{OH}^{-}\right.$, benzoate, 2-(4-bromophenyl)acetate) with $\mathrm{NOBF}_{4}$. Bottom: Bottom: crystal structures of 12 (left) and the $f a c-\left[\operatorname{Re}(\mathrm{CO})_{2}(\mathrm{NO})(\mathrm{N}-\mathrm{N})\left(\mathrm{CH}_{3} \mathrm{CN}\right)\right]^{2+}$ ion $(\mathbf{1 3})$. Thermal ellipsoids are at 30\% probability. Selected bond lengths ( $\left.\AA^{\prime}\right)$ for 12: Re-F1 2.082(4), Re-N1 2.137(6), Re-N2 2.132(5), Re-N3 1.794(7), Re-CO 1.999(9) and 1.985(9), C-O 1.123(10) and 1.125(10), N-O 1.139(8); for 13: Re-N1 2.145(5), Re-N2 2.139(6), Re-N3 1.791(5), Re-N4 2.079(6), Re-CO 1.991(7) and 1.997(8), C-O 1.118(9) and 1.123(9), N-O 1.151(7). Selected bond angles $\left(^{\circ}\right)$ : 12, O3-N3-Re1 177.8(8); 13, O1-N3-Re1 177.5(5). 


\subsection{X-ray Crystallography}

Crystallographic details of all complexes reported here are in Supplementary Materials, while selected bond lengths of $f a c-\left[\operatorname{Re}(\mathrm{CO})_{2}(\mathrm{NO})\right]^{2+}$ species are given in figure captions. All rhenium dicarbonyl-nitrosyl complexes show a distorted octahedral geometry around the Re ion. Structural analysis of the species and comparison to related $f a c-\left[\operatorname{Re}(\mathrm{CO})_{3}\right]^{+}$ species, revealed the following general characteristics. Within $3 \sigma$, the Re-CO and the $\mathrm{C} \equiv \mathrm{O}$ bonds are respectively longer and shorter than the corresponding tricarbonyl complexes. There is no significant statistical difference in the Re-Br bond, while the Re-N(diamine) is slightly shorter in $f a c-\left[\operatorname{Re}(\mathrm{CO})_{2}(\mathrm{NO})\right]^{2+}$ species. In these, overall, crystal parameters are consistent with a rhenium ion in a higher oxidation state than +1 and are in agreement with the spectroscopic data. The shorter $\mathrm{C} \equiv \mathrm{O}$ distances, e.g., are clearly reflected in the higher frequency of vibration of the bond in the IR spectrum. Likewise, the longer $\mathrm{N}-\mathrm{O}$ distance (by ca. $0.1 \AA$ in comparison to the free ion [50,51]) of Re-bound NO is observed in a lower frequency vibration of the same. Perhaps the most striking feature in $f a c-\left[\operatorname{Re}(\mathrm{CO})_{2}(\mathrm{NO})(\mathrm{N}-\right.$ $\mathrm{N}) \mathrm{Br}]^{+}$species (1-5) is represented by the bending (ca. $17^{\circ}$, but up to $25^{\circ}$ for complex 7 ) of the diamine ligand away from the bound $\mathrm{NO}$ (the diimine and the $\operatorname{Re}(\mathrm{CO})_{2}$ planes define the angle). In comparison, the same angle measures $4-6^{\circ}$ in corresponding tricarbonyl molecules, and ca. $11^{\circ}$ for $\mathbf{1 2}$ and 13. Similarly, in nitrosyl complexes 1-5, the two COs are also slightly bent towards the same direction (Figure 7). Overall, the molecules appear to be moving towards a trigonal distortion observed in octahedral $\mathrm{d}^{4}$ complexes [52].

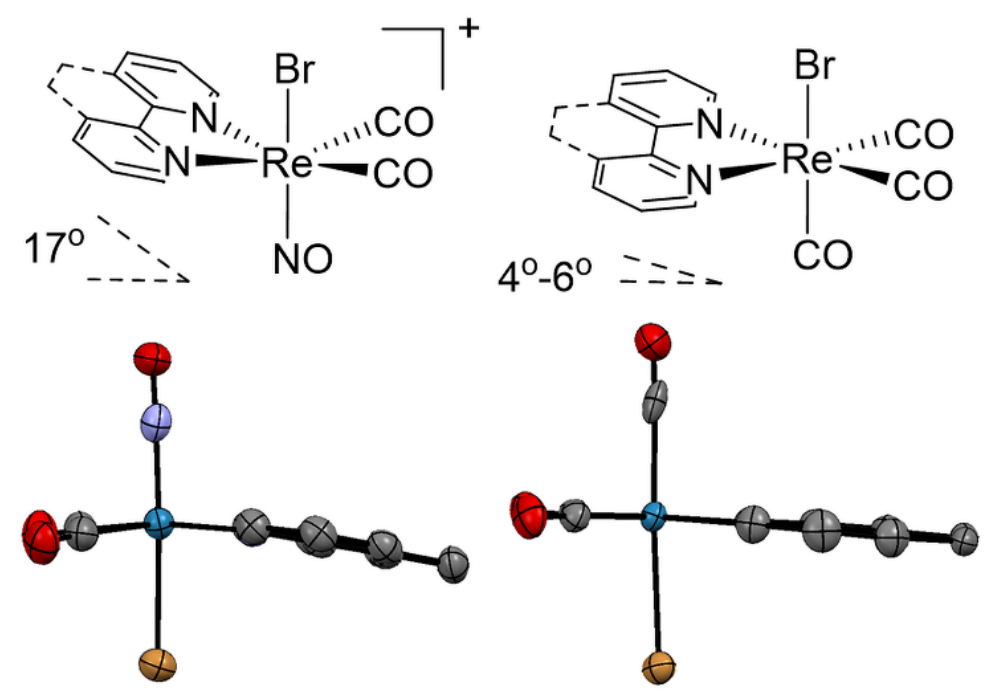

Figure 7. Main structural differences between related diimine $f a c-\left[\operatorname{Re}(\mathrm{CO})_{2}(\mathrm{NO})\right]^{2+}$ and $f a c-\left[\operatorname{Re}(\mathrm{CO})_{3}\right]^{+}$ species. At the bottom we compare the structures of $\mathbf{2}$ and a tricarbonyl phen derivative [53].

\subsection{CO Releasing Properties}

In the initial phases of our investigation, we also probed the direct nitrosylation of tricarbonyl complexes with ortho-substituted $\alpha$-diimines. The reaction is generally lower yielding with these ligands, but it works as well. In synthetic terms, nitrosylation of the complex bearing 6-methyl-2,2'-bipyridine (6Me-bpy) gave the best results (67\% yield). We found, however, that when $\mathrm{CH}_{3} \mathrm{CN}$ solutions of $f a c-\left[\operatorname{Re}(\mathrm{CO})_{2}(\mathrm{NO})(6 \mathrm{Me}-\mathrm{bpy}) \mathrm{Br}\right] \mathrm{BF}_{4}(\mathbf{1 4})$ were left exposed to ambient light, over time, crystals of the fully oxidized perrhenate ion appeared (Figure 8). 

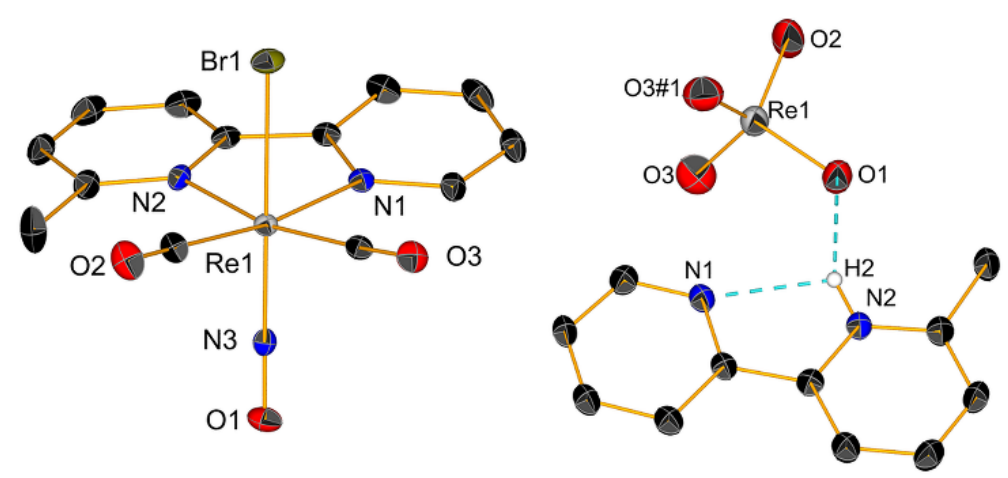

Figure 8. Crystal structures of compounds 14 (left) and its fully oxidized product. Thermal ellipsoids are at $30 \%$ probability. Hydrogen atoms and $\mathrm{BF}_{4}{ }^{-}$counter ion omitted for clarity. Selected bond lengths for 14 (Å): Re-N1 2.135(4), Re-N2 2.188(4), Re-N3 1.784(4), Re-Br 2.5358(5), Re-CO 2.006(5) and 1.975(5), C-O 1.120(6) and 1.135(6), N-O 1.161(5). Selected bond angles ( $\left.{ }^{\circ}\right)$ : 14, O1-N3-Re1 177.8(4).

This observation indicated to us either that steric hindrance at the ortho position of the $\alpha$-diimine ligand can destabilize $f a c-\left[\operatorname{Re}(\mathrm{CO})_{2}(\mathrm{NO})\right]^{2+}$ species which can then be oxidized by $\mathrm{O}_{2}$ to $\mathrm{ReO}_{4}{ }^{-}$, or that the complexes are photo-labile towards $\mathrm{CO}$ (and/or NO) release, i.e., acting as photoCORMs. Marti has shown that, unlike the tricarbonyl congener, the $f a c-\left[\operatorname{Re}(\mathrm{CO})_{2}(\mathrm{NO}) \mathrm{Br}_{3}\right]^{-}$ion reacts with tetradentate chelating ligands giving monocarbonyl-mononitrosyl species, indicative of a tendency of the rhenium dicarbonylnitrosyl complexes to liberate $\mathrm{CO}$ if specific conditions are satisfied [25]. Consequently we probed the CO-releasing properties of the $f a c-\left[\operatorname{Re}(\mathrm{CO})_{2}(\mathrm{NO})(\mathrm{N}-\mathrm{N}) \mathrm{X}\right]^{+}$molecules under conditions of the standard myoglobin $(\mathrm{Mb})$ assay in the presence and absence of light.

Spectrophotometric measurements of the CO release from complexes 1-5 and $\mathbf{1 4}$, as a function of the conversion of deoxy- $\mathrm{Mb}$ to $\mathrm{MbCO}$, revealed that dicarbonyl-mononitrosyl complexes only released the gas if exposed to a cold light source of $275-375 \mathrm{~nm}$ radiation. In the dark, the complexes are stable and do not elicit any change in the deoxy-Mb spectrum. A typical spectrum of the conversion of the deoxy-Mb spectrum under photolysis of 1-5 and $\mathbf{1 4}$ is given in Figure 9. The equivalents of $\mathrm{CO}$ released by the molecules were calculated by measuring the change of absorbance at $540 \mathrm{~nm}\left(\varepsilon_{540}=15.4 \mathrm{mmol} \mathrm{L}^{-1} \mathrm{~cm}^{-1}\right)$, as a direct measure of the concentration of $\mathrm{MbCO}$. The amount of the formed $\mathrm{MbCO}$ is dependent on the concentration of the complex, but analysis of the saturation curve of $\mathrm{MbCO}$ showed, that for all tested complexes approximately 0.6-0.7 moles $\mathrm{CO}$ are released per mole of complex. In Figure 9, the peak at $620 \mathrm{~nm}$ is attributable to the formation of metmyoglobin (MetMb) after prolonged exposure to the light source [54]. The loss of CO was verified by MS experiments, whereby solutions of the complexes were irradiated under similar conditions in $\mathrm{CH}_{3} \mathrm{CN}$ solutions. The spectra consistently revealed that only $\mathrm{CO}$ is released by the species during the irradiation process and that a solvent molecule replaces the ligand.

To our knowledge, $f a c-\left[\operatorname{Re}(\mathrm{CO})_{2}(\mathrm{NO})(\mathrm{N}-\mathrm{N}) \mathrm{Br}\right]^{+}$complexes represent a new class of $\operatorname{Re}$ photoCORMs. Spontaneous and light-induced CO release of 16- and 17-electron rhenium complexes [55-57], and 18-electron $f a c-\left[\operatorname{Re}^{\mathrm{I}}(\mathrm{CO})_{3}(\mathrm{~N}-\mathrm{N}) \mathrm{PR}_{3}\right]^{+}$(where $\mathrm{PR}_{3}=$ phosphine or phosphite) is well known [58-60]. In the last five years several examples of diimine complexes bearing either $\sigma$ - or $\pi$-donating ancillary ligands active towards $\mathrm{CO}$ photosubstitution have also been described [61-65]. For $\mathrm{PR}_{3}$ species, the strong trans-labilizing ability of the phosphorus donor of $\pi$-acid ligands is crucial for activating Re tricarbonyl species towards photochemical substitution of $\mathrm{CO}$, and works in conjunction with the internal conversion between the ${ }^{3} \mathrm{MLCT}$ and thermally accessible higher energy photoexcited ${ }^{3} \mathrm{LF}$ state that is productive in terms of $\mathrm{CO}$ dissociation [66]. For tricarbonyl rhenium diimine complexes with $\pi$-basic ligands, mechanistic studies and picosecond time-resolved IR measurements indicate that only irradiation with higher energy photons can induce photochemical ligand substitution reactions via higher energy vibrational states rather than the lowest-lying ${ }^{3}$ MLCT excited or thermally accessible ${ }^{3}$ LF states. These higher 
vibrational levels are those of the ${ }^{1} \mathrm{MLCT}$ state and/or higher electronic excited state(s) including the $\mathrm{Re} \rightarrow \mathrm{CO}^{1} \mathrm{MLCT}$ transition. Thus, excitation by high-energy light of fac$\left[\operatorname{Re}(\mathrm{CO})_{3}(\mathrm{~N}-\mathrm{N})(\mathrm{L})\right]^{\mathrm{n}}$ species (were $\mathrm{L}=\pi$-base or $\sigma$-donor ligand), leads to vibrationally hot photoproducts, which relax within $50-100$ ps, while CO ligand dissociation occurs with subpicosecond rates after excitation [67]. A similar mechanism is likely to be at play here.
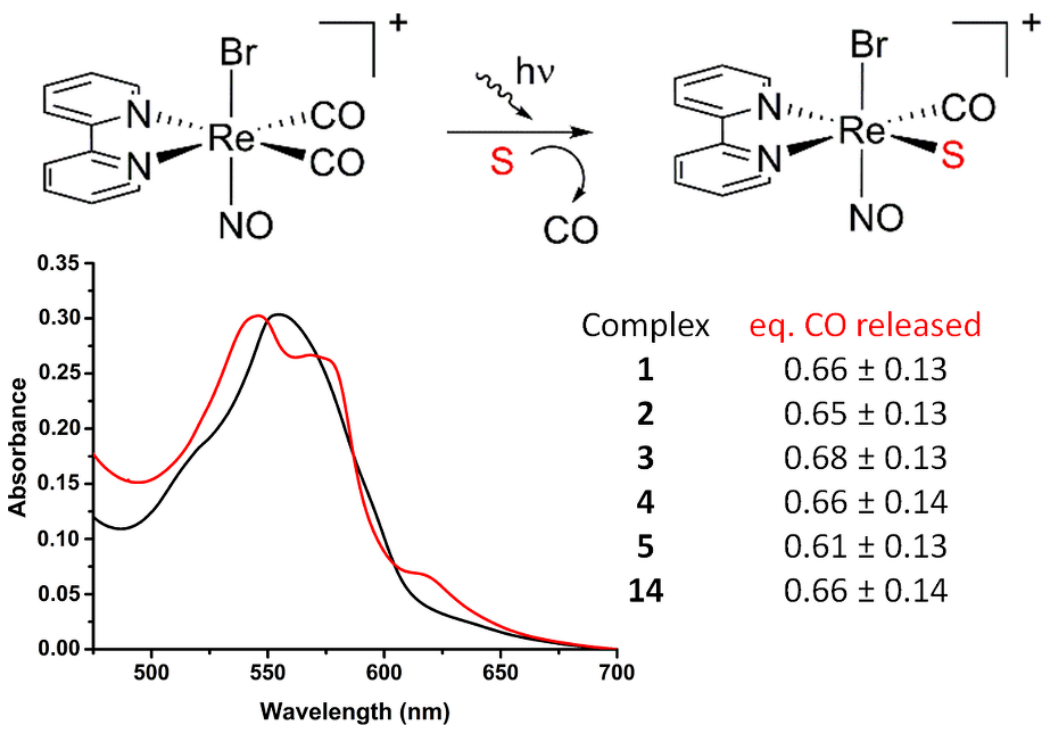

eq. CO released

$1 \quad 0.66 \pm 0.13$

$20.65 \pm 0.13$

$3 \quad 0.68 \pm 0.13$

$0.66 \pm 0.14$

$5 \quad 0.61 \pm 0.13$

$14 \quad 0.66 \pm 0.14$

Figure 9. Typical UV-visible spectrum of conversion of deoxy-myoglobin (deoxy-Mb) to carbon monoxide myoglobin $(\mathrm{MbCO})$ by fac- $\left[\operatorname{Re}^{\mathrm{I}}(\mathrm{CO})_{2}(\mathrm{NO})(\mathrm{N}-\mathrm{N}) \mathrm{Br}\right] \mathrm{BF}_{4}$ complexes $\mathbf{1}-\mathbf{5}$ and $\mathbf{1 4}$. Solutions $\left(20 \mu \mathrm{M} \mathrm{Mb}\right.$ and photoCORM, $25^{\circ} \mathrm{C}, 0.05 \mathrm{M}$ phosphate buffer at $\mathrm{pH}$ 6.8) were exposed to a $275 \mathrm{~nm}$ light source (intervals of $10 \mathrm{~min}$ ) before the conversion reached a plateau after $120 \mathrm{~min}$. Prolonged exposure to the light source eventually favoured formation of metmyoglobin (MetMb), as evidenced by the peak at $620 \mathrm{~nm}$. In the reaction scheme above the spectra, $S=$ solvent molecule.

\subsection{Antimicrobial Properties of Selected Complexes}

As mentioned in the introduction, this study was initiated aiming at the synthesis of structurally nearly identical higher charge congeners of active antimicrobial rhenium tricarbonyl complexes. Our previous reports on those species indicate that neutral fac$\left[\operatorname{Re}(\mathrm{CO})_{3}(\mathrm{~N}-\mathrm{N}) \mathrm{Br}\right]$ bromo complexes are inactive, whereas several cationic complexes of general formula $f a c-\left[\operatorname{Re}(\mathrm{CO})_{3}(\mathrm{~N}-\mathrm{N}) \mathrm{L}\right]^{+}(\mathrm{L}=$ pyridine, py, type-ligand) show potent in vitro and in vivo activity against infection of clinically relevant bacteria (MRSA) and fungi (Candida species) $[19,20]$. We did not succeed in isolating stable $f a c-\left[\operatorname{Re}(\mathrm{CO})_{2}(\mathrm{NO})(\mathrm{N}-\right.$ $\mathrm{N}) \mathrm{L}]^{2+}$ species, but we decided to test the antimicrobial properties of the corresponding monocationic nitrosyl complexes fac- $\left[\operatorname{Re}(\mathrm{CO})_{2}(\mathrm{NO})(\mathrm{N}-\mathrm{N}) \mathrm{X}\right]^{+}(\mathbf{1}-\mathbf{4}$ and $\mathbf{1 2}$, where $\mathrm{X}=\mathrm{Br}$ or $\mathrm{BF}_{4}$ ). The antimicrobial activity of $\mathbf{1}-\mathbf{4}$ and $\mathbf{1 2}$ was determined against four Gram-negarive bacteria (E. cloaceae, K. pneumoniae, A. baumanii, and P. aeruginosa), two Gram-positive bacteria (S. aureus MRSA43300 and S. aureus) and two fungi (C. albicans and C. auris) and compared to the corresponding $f a c-\left[\operatorname{Re}(\mathrm{CO})_{3}(\mathrm{~N}-\mathrm{N}) \mathrm{Br}\right]$ complexes. Our data indicate that the tested $f a c-\left[\operatorname{Re}(\mathrm{CO})_{2}(\mathrm{NO})(\mathrm{N}-\mathrm{N}) \mathrm{X}\right]^{+}$species behave as the corresponding neutral fac$\left[\operatorname{Re}(\mathrm{CO})_{3}(\mathrm{~N}-\mathrm{N}) \mathrm{Br}\right]$ complexes and none of these complexes exhibited antimicrobial activity, with minimum inhibitory concentrations (MICs) $>100 \mu \mathrm{M}$.

\section{Materials and Methods}

\subsection{Reagents and Chemicals}

All reagent and solvents were purchased from standard sources and used without further purification. Compound $\left[\operatorname{Re}(\mathrm{CO})_{5} \mathrm{Br}\right]$ was purchased from Sigma Aldrich, while complexes of formula $f a c-\left[\operatorname{Re}^{\mathrm{I}}(\mathrm{CO})_{3}(\mathrm{~N}-\mathrm{N}) \mathrm{Br}\right][19],\left(\mathrm{Et}_{4} \mathrm{~N}\right)\left[\operatorname{Re}^{\mathrm{II}}(\mathrm{CO})_{2} \mathrm{Br}_{4}\right][36], f a c-\left[\operatorname{Re}^{\mathrm{I}}(\mathrm{CO})_{2}(\mathrm{~N}-\right.$ $\left.\mathrm{N})(\mathrm{py}) \mathrm{Br}][\text { [37], fac-[Re(CO) })_{3}(\mathrm{bpy}) \mathrm{OH}\right][68]$ and $\mathrm{fac}-\left[\mathrm{Re}(\mathrm{CO})_{3}(\mathrm{bpy})\left(\mathrm{Me}_{2} \mathrm{~N}-\mathrm{py}\right)\right]\left(\mathrm{CF}_{3} \mathrm{SO}_{3}\right)[46]$ 
were synthesized according to published procedures. Unless otherwise noted, solvents used in the preparation of all molecules were dry and $\mathrm{O}_{2}$-free.

\subsection{Instruments and Analysis}

NMR spectra were measured on a Bruker Advance III $400 \mathrm{MHz}$. The corresponding

${ }^{1} \mathrm{H}$ chemical shifts are reported relative to residual solvent protons. Mass analyses were performed using a Bruker FTMS 4.7-T Apex II in positive mode. UV-Vis spectra were measured on a Jasco V730 spectrophotometer. IR spectra were recorded on a Bruker TENSOR II with the following parameters: 16 scans for background, 32 scans for sample with a resolution of $4 \mathrm{~cm}^{-1}$ in the $4000-600 \mathrm{~cm}^{-1}$ region. Single crystal diffraction data collection was performed on a Stoe IPDS2 diffractometer (CuK $\alpha 1(\lambda=1.5406 \AA))$ equipped with a cryostat from Oxford Cryosystems. The structures were solved with the ShelXT structure solution program using Intrinsic Phasing and refined with the ShelXL refinement package using Least Squares minimization [69,70]. All crystal structures are deposited at the Cambridge Crystallographic Data Centre. CCDC numbers 2093631-2093640 and 2094070 contain the supplementary crystallographic data for this paper. These data can be obtained free of charge from the Cambridge Crystallographic Data Centre via www.ccdc. cam.ac.uk/structures (accessed on 20 July 2021).

\subsection{Synthetic Procedures}

The following general procedure was followed for the synthesis of $\left[\operatorname{Re}(\mathrm{CO})_{2}(\mathrm{NO})(\mathrm{N}-\right.$ $\mathrm{N}) \mathrm{Br} \mathrm{BF}_{4}$ complexes. In a glove box the corresponding $f a c-\left[\operatorname{Re}(\mathrm{CO})_{3}(\mathrm{~N}-\mathrm{N}) \mathrm{Br}\right]$ (typically $0.2 \mathrm{mmol}$ ca. $100 \mathrm{mg}$ ) was dissolved in $\mathrm{CH}_{2} \mathrm{Cl}_{2}$ (100 mL, dry). To the resulting yellow solution, $\mathrm{NOBF}_{4}(84-115 \mathrm{mg}, 0.5-1 \mathrm{mmol}, 2.5-5$ eq.) was added in the solid form. The reaction was stirred at room temperature for 2 days. A light off-white precipitate was filtered off and the filtrate either allowed to evaporate or layered with pentane to afford light yellow crystals, which were collected by filtration.

$\left[\operatorname{Re}(\mathbf{C O})_{2}(\mathbf{N O})(\mathbf{b p y}) \mathbf{B r}\right]\left(\mathbf{B F}_{4}\right)(\mathbf{1})$. Yellow solid, yield $70 \%$. ESI ${ }^{+}-\mathrm{MS}(\mathrm{MeOH}): m / z$, $507.7\left[\operatorname{Re}(\mathrm{CO})_{2}(\mathrm{NO})\left(\mathrm{C}_{10} \mathrm{H}_{8} \mathrm{~N}_{2}\right) \mathrm{Br}\right]^{+}$, [M] ${ }^{+}$. IR (solid, $\left.\mathrm{cm}^{-1}\right) ;$; $\mathrm{CO}: 2112$, 2050, vNO: 1801. ${ }^{1} \mathrm{H}-\mathrm{NMR}\left(400 \mathrm{MHz}, \mathrm{CD}_{3} \mathrm{CN}, \mathrm{ppm}\right): 7.87$ (ddd, $\left.J=7.70,5.62,1.34 \mathrm{~Hz}, 2 \mathrm{H}\right) 8.48$ (td, $J=7.98,1.53 \mathrm{~Hz}, 2 \mathrm{H}) 8.64(\mathrm{~d}, J=8.19 \mathrm{~Hz}, 2 \mathrm{H}) 9.22-9.30(\mathrm{~m}, 2 \mathrm{H})$. UV-Vis $\left(\mathrm{CH}_{3} \mathrm{CN}, \lambda \mathrm{nm}\right)$ : 312,321 . Crystals suitable for $\mathrm{X}$-ray diffraction were obtained by slow evaporation of a dichloromethane solution. Elemental analysis, calcd. for $\mathrm{C}_{12} \mathrm{H}_{8} \mathrm{~B}_{1} \mathrm{Br}_{1} \mathrm{~F}_{4} \mathrm{~N}_{3} \mathrm{O}_{3} \mathrm{Re}_{1}$ (\%): C 24.22, H 1.36, N 7.06; found: C 24.11, H 1.29, N 7.04.

$\left[\operatorname{Re}(\mathrm{CO})_{2}(\mathrm{NO})(\right.$ phen $) \mathbf{B r}\left(\mathbf{B F}_{4}\right)(2)$. Yellow solid, yield $55 \%$. ESI ${ }^{+}-\mathrm{MS}(\mathrm{MeOH}): m / z$, $531.6\left[\operatorname{Re}(\mathrm{CO})_{2}(\mathrm{NO})\left(\mathrm{C}_{12} \mathrm{H}_{8} \mathrm{~N}_{2}\right) \mathrm{Br}\right]^{+},[\mathrm{M}]^{+}$. IR (solid, $\left.\mathrm{cm}^{-1}\right) ; v C O: 2118,2057, v N O: 1790$. ${ }^{1}$ H-NMR (400 MHz, DMSO-d6, ppm): 8.34 (dd, J = 8.31, $\left.5.26 \mathrm{~Hz}, 2 \mathrm{H}\right) 8.49$ (s, 2 H) 9.25 (dd, $J=8.31,1.22 \mathrm{~Hz}, 2 \mathrm{H}) 9.89$ (dd, $J=5.26,1.22 \mathrm{~Hz}, 2 \mathrm{H})$. UV-Vis $\left(\mathrm{CH}_{3} \mathrm{CN}, \lambda \mathrm{nm}\right): 304,339,375$. Crystals suitable for $\mathrm{X}$-ray diffraction were obtained from layering a solution of acetonitrile with diethylether/hexane (1:1). Elemental analysis, calcd. for $\mathrm{C}_{14} \mathrm{H}_{8} \mathrm{~B}_{1} \mathrm{Br}_{1} \mathrm{~F}_{4} \mathrm{~N}_{3} \mathrm{O}_{3} \operatorname{Re}_{1}(\%)$ : C 27.16, H 1.30, N 6.79; found: C 27.61, H 1.33, N 6.66.

$\left[\operatorname{Re}(\mathrm{CO})_{2}(\mathrm{NO})\left(\mathrm{Et}_{2} \mathbf{N}-\mathrm{bpy}\right) \mathbf{B r}\right]\left(\mathrm{BF}_{4}\right)(3) . \quad \mathrm{Et}_{2} \mathrm{~N}-\mathrm{bpy}=\mathrm{N}^{4}, \mathrm{~N}^{4}, \mathrm{~N}^{4^{\prime}}, \mathrm{N}^{4^{\prime}}$-tetraethyl-[2,2'bipyridine]-4,4'-diamine. Yellow solid, yield $87 \%$. $\mathrm{ESI}^{+}-\mathrm{MS}(\mathrm{MeOH}): m / z, 649.8\left[\operatorname{Re}(\mathrm{CO})_{2}\right.$ (NO) $\left.\left(\mathrm{C}_{18} \mathrm{H}_{26} \mathrm{~N}_{4}\right) \mathrm{Br}\right]^{+}$, [M] ${ }^{+}$. IR (solid, $\mathrm{cm}^{-1}$ ); vCO: 2104, 2040, vNO: 1770. ${ }^{1} \mathrm{H}-\mathrm{NMR}$ (400 MHz, CD $\left.{ }_{3} \mathrm{CN}, \mathrm{ppm}\right): 1.22-1.28(\mathrm{~m}, 12 \mathrm{H}) 3.64$ (br. s., $\left.8 \mathrm{H}\right) 6.79(\mathrm{dd}, J=7.03,2.87 \mathrm{~Hz}$, $2 \mathrm{H}) 7.37(\mathrm{~d}, J=2.93 \mathrm{~Hz}, 2 \mathrm{H}) 8.51(\mathrm{~d}, J=7.09 \mathrm{~Hz}, 2 \mathrm{H})$. UV-Vis $\left(\mathrm{CH}_{3} \mathrm{CN}, \lambda \mathrm{nm}\right): 342,357$. Elemental analysis, calcd. for $\mathrm{C}_{20} \mathrm{H}_{26} \mathrm{~B}_{1} \mathrm{Br}_{1} \mathrm{~F}_{4} \mathrm{~N}_{5} \mathrm{O}_{3} \mathrm{Re}_{1}$ (\%): C 32.58, H 3.55, N 9.50; found: C 33.14, H 3.60, N 9.32.

$\left[\operatorname{Re}(\mathrm{CO})_{2} \mathbf{N O}(t \mathrm{Bu}\right.$-bpy $\left.) \mathbf{B r}\right]\left(\mathrm{BF}_{4}\right)(4) . t$ Bu-bpy $=4,4^{\prime}$-di-tert-butyl-2,2'-bipyridine. Yellow solid, yield 69\%. ESI ${ }^{+}$-MS $(\mathrm{MeOH}): m / z, 619.7\left[\operatorname{Re}(\mathrm{CO})_{2}(\mathrm{NO})\left(\mathrm{C}_{18} \mathrm{H}_{24} \mathrm{~N}_{2}\right) \mathrm{Br}\right]^{+},[\mathrm{M}]^{+}$. IR (solid, $\mathrm{cm}^{-1}$ ); vCO: 2114, 2053, vNO: 1797. ${ }^{1} \mathrm{H}$ NMR (400 MHz, $\mathrm{CD}_{3} \mathrm{CN}, \mathrm{ppm}$ ): $1.42-1.54$ $(\mathrm{m}, 18 \mathrm{H}) 7.84(\mathrm{dd}, J=6.05,2.02 \mathrm{~Hz}, 2 \mathrm{H}) 8.58-8.61(\mathrm{~m}, 2 \mathrm{H}) 9.09-9.14(\mathrm{~m}, 2 \mathrm{H})$. UV-Vis $\left(\mathrm{CH}_{3} \mathrm{CN}, \lambda \mathrm{nm}\right): 309$, 318. Elemental analysis, calcd. for $\mathrm{C}_{20} \mathrm{H}_{24} \mathrm{~B}_{1} \mathrm{Br}_{1} \mathrm{~F}_{4} \mathrm{~N}_{3} \mathrm{O}_{3} \mathrm{Re}_{1}(\%): \mathrm{C}$ 33.96, H 3.42, N 5.94; found: C 34.36, H 3.47, N 5.72. 
$\left[\operatorname{Re}(\mathrm{CO}){ }_{2} \mathrm{NO}(\varphi\right.$-phen $\left.) \mathrm{Br}\right]\left(\mathrm{BF}_{4}\right)(5) . \varphi$-phen $=4,7$-diphenyl-1,10-phenanthroline. Yellow solid, yield 61\%. ESI ${ }^{+}$MS $(\mathrm{MeOH}): m / z, 683.7\left[\operatorname{Re}(\mathrm{CO})_{2}(\mathrm{NO})\left(\mathrm{C}_{24} \mathrm{H}_{16} \mathrm{~N}_{2}\right) \mathrm{Br}\right]^{+},[\mathrm{M}]^{+}$. IR (solid, $\mathrm{cm}^{-1}$ ); vCO: 2114, 2052, vNO: 1795. ${ }^{1} \mathrm{H}-\mathrm{NMR}$ (400 MHz, $\mathrm{CD}_{3} \mathrm{CN}, \mathrm{ppm}$ ): 7.69-7.73 $(\mathrm{m}, 10 \mathrm{H}) 8.14(\mathrm{~d}, J=5.50 \mathrm{~Hz}, 2 \mathrm{H}) 8.26(\mathrm{~s}, 2 \mathrm{H}) 9.69(\mathrm{~d}, J=5.62 \mathrm{~Hz}, 2 \mathrm{H})$. UV-Vis $\left(\mathrm{CH}_{3} \mathrm{CN}, \lambda\right.$ nm): 297, 336, 375. Elemental analysis, calcd. for $\mathrm{C}_{26} \mathrm{H}_{16} \mathrm{~B}_{1} \mathrm{Br}_{1} \mathrm{~F}_{4} \mathrm{~N}_{3} \mathrm{O}_{3} \operatorname{Re}_{1}(\%)$ : C $40.49, \mathrm{H}$ 2.09, N 5.45; found: C 40.89, H 2.15, N 5.13.

$\left[\operatorname{Re}(\mathbf{C O})_{2}(\mathbf{N O})(\mathbf{b p y}) \mathbf{F}\right]\left(\mathbf{B F}_{4}\right)(6)$. Complex $\mathbf{1}(50.7 \mathrm{mg})$ was dissolved in methanol $(5 \mathrm{~mL})$ and the solution was heated to $55^{\circ} \mathrm{C}$. Pyridine $(20.2 \mathrm{mg})$ and silver triflate $(33 \mathrm{mg})$ were added in the dark. The mixture was stirred at $55^{\circ} \mathrm{C}$ overnight. After filtration, the filtrate was dried under reduced pressure. The crude product was then dissolved in a minimal amount of methanol and precipitated with cold diethylether to give 6 as a white/pale yellow solid (11.4 mg, 25\%) which contained traces of pyridine. ESI ${ }^{+}$-MS $(\mathrm{MeOH}): m / z, 447.9\left[\operatorname{Re}(\mathrm{CO})_{2}(\mathrm{NO})\left(\mathrm{C}_{10} \mathrm{H}_{8} \mathrm{~N}_{2}\right) \mathrm{F}\right]^{+},[\mathrm{M}]^{+}$. IR (solid, $\left.\mathrm{cm}^{-1}\right): v \mathrm{CO}: 2113,2051$, vNO: 1779. ${ }^{1} \mathrm{H}-\mathrm{NMR}\left(400 \mathrm{MHz}, \mathrm{CD}_{3} \mathrm{CN}, \mathrm{ppm}\right): 8.65$ (ddd, $\left.J=4.7,1.7,1.0 \mathrm{~Hz}, 2 \mathrm{H}\right), 8.41$ $(\mathrm{dt}, J=8.0,1.0 \mathrm{~Hz}, 2 \mathrm{H}), 7.89(\mathrm{td}, J=7.8,1.8 \mathrm{~Hz}, 2 \mathrm{H}), 7.38 \mathrm{ppm}(\mathrm{ddd}, J=7.5,4.8,1.2 \mathrm{~Hz}$, $2 \mathrm{H}$ ). UV-Vis (DMF, nm): 307,316 . Crystals suitable for X-ray diffraction were obtained by layering diethylether on a methanol solution of the compound.

$\left[\operatorname{Re}(\mathbf{C O})_{2}(\mathbf{N O})\left(\mathbf{E t}_{2} \mathbf{N}-\mathbf{b p y}\right) \mathbf{F}\right]\left(\mathbf{B F}_{4}\right)(7)$. Complex $3(80.0 \mathrm{mg})$ was dissolved in $5 \mathrm{~mL}$ of methanol. The solution was then heated to $55^{\circ} \mathrm{C}$ and pyridine $(25.8 \mathrm{mg}, 3$ eq.) was added followed by the addition of silver triflate $(41.8 \mathrm{mg}, 1.5 \mathrm{eq}$.$) in the dark. The reaction$ mixture was stirred over night at $55^{\circ} \mathrm{C}$, filtered and the solvent evaporated. The crude product was then dissolved in a minimal amount of methanol and precipitated with cold diethylether to give 7 as a white/beige solid $(21.0 \mathrm{mg}$, ca. $29 \%)$ which contained traces of pyridine. ESI ${ }^{+}$-MS $(\mathrm{MeOH}): m / z, 589.67\left[\mathrm{Re}(\mathrm{CO}){ }_{2}(\mathrm{NO})\left(\mathrm{C}_{18} \mathrm{H}_{26} \mathrm{~N}_{4}\right) \mathrm{F}\right]^{+}$, [M] $]^{+}$. IR (solid, $\left.\mathrm{cm}^{-1}\right)$ : vCO: 2106, 2033, vNO: $1784 .{ }^{1} \mathrm{H}-\mathrm{NMR}\left(400 \mathrm{MHz}, \mathrm{CD}_{3} \mathrm{CN}, \mathrm{ppm}\right): 1.25(\mathrm{t}, J=7.15 \mathrm{~Hz}$, $12 \mathrm{H}) 3.63(\mathrm{~d}, J=7.09 \mathrm{~Hz}, 8 \mathrm{H}) 6.77(\mathrm{dd}, J=7.09,2.93 \mathrm{~Hz}, 2 \mathrm{H}) 7.35(\mathrm{~d}, J=2.81 \mathrm{~Hz}, 2 \mathrm{H})$ $7.99(\mathrm{t}, J=7.09 \mathrm{~Hz}, 2 \mathrm{H}) 8.46-8.60(\mathrm{~m}, 3 \mathrm{H}) 8.69(\mathrm{~d}, J=5.26 \mathrm{~Hz}, 2 \mathrm{H})$. UV-Vis (DMF, nm): 342,352 . Crystals suitable for $\mathrm{X}$-ray diffraction were obtained by layering diethylether on a methanol solution of the compound.

$\left[\operatorname{Re}(\mathrm{CO})_{2}(\mathbf{p y})(\mathbf{b p y}) \mathbf{B r}\right](8)$. This complex was prepared by following a previously published procedure for similar species [37]. Brown solid, yield 80\%. IR (solid, $\mathrm{cm}^{-1}$ ); $v$ CO: 1864, 1781. ${ }^{1} \mathrm{H}-\mathrm{NMR}\left(400 \mathrm{MHz}, \mathrm{CD}_{2} \mathrm{Cl}_{2}, \mathrm{ppm}\right): 6.83(\mathrm{dd}, J=7.52,6.66 \mathrm{~Hz}, 2 \mathrm{H}) 7.37-7.49$ $(\mathrm{m}, 3 \mathrm{H}) 7.89(\mathrm{td}, J=7.89,1.47 \mathrm{~Hz}, 2 \mathrm{H}) 8.09(\mathrm{~d}, J=8.07 \mathrm{~Hz}, 2 \mathrm{H}) 8.37(\mathrm{dd}, J=6.60,1.47 \mathrm{~Hz}$, $2 \mathrm{H}) 9.16(\mathrm{~d}, J=5.38 \mathrm{~Hz}, 2 \mathrm{H})$. UV-Vis (DMF, $\lambda \mathrm{nm}$ ): 393, 308. Crystals suitable for X-ray diffraction were obtained by layering pentane on a DCM solution of the compound.

$\left[\operatorname{Re}(\mathrm{CO})_{2} \mathrm{NO}(\right.$ bpy $)\left(\mathrm{Me}_{2} \mathrm{~N}\right.$-py) $]\left(\mathrm{BF}_{4}\right)_{2}(\mathbf{9})$. In a glove box fac- $\left[\operatorname{Re}(\mathrm{CO})_{3}(\mathrm{bpy})\left(\mathrm{Me}_{2} \mathrm{~N}\right.\right.$ py)] $\left(\mathrm{CF}_{3} \mathrm{SO}_{3}\right)[46]$ (30 mg, $0.043 \mathrm{mmol}$, where $\mathrm{Me}_{2} \mathrm{~N}$-py $=\mathrm{N}, \mathrm{N}$-dimethylpyridin-4-amine) was dissolved in $\mathrm{CH}_{2} \mathrm{Cl}_{2}\left(30 \mathrm{~mL}\right.$, dry) and to the resulting yellow solution, $\mathrm{NOBF}_{4}(10 \mathrm{mg}$, 2 eq.) was added in the solid form. The reaction was stirred at room temperature for 2 days. A light yellow solid appeared. It was filtered off, washed with cold $\mathrm{CH}_{2} \mathrm{Cl}_{2}$ and dried in vacuo. Attempts to purify the salt led to the decomposition of the product. Yield $62 \%$. IR (solid, $v \mathrm{CO} \mathrm{cm}^{-1}$ ): 2129, 2070, vNO: $1830 .{ }^{1} \mathrm{H}$ NMR (400 MHz, $\mathrm{CD}_{3} \mathrm{CN}, \mathrm{ppm}$ ): 9.24-9.31 $(\mathrm{m}, 2 \mathrm{H}), 8.67-8.73(\mathrm{~m}, 2 \mathrm{H}), 8.52-8.61(\mathrm{~m}, 2 \mathrm{H}), 7.98-8.02(\mathrm{~m}, 2 \mathrm{H}), 7.91-7.97(\mathrm{~m}, 2 \mathrm{H}), 6.87(\mathrm{~d}$, $\mathrm{J}=6.85 \mathrm{~Hz}, 2 \mathrm{H}), 3.19-3.22(\mathrm{~m}, 6 \mathrm{H})$.

The $f a c-\left[\operatorname{Re}(\mathrm{CO})_{3}(\mathrm{bpy})\right]$ carboxylato complexes were prepared by adaptation of a published procedure [71]. Briefly, $f a c-\left[\operatorname{Re}(\mathrm{CO})_{3}(\mathrm{bpy}) \mathrm{Br}\right](100 \mathrm{mg}, 0.2 \mathrm{mmol})$ and the appropriate carboxylic acid ligand were dissolved in anhydrous degassed tetrahydrofuran $(30 \mathrm{~mL})$. The reaction mixture was stirred for $5 \mathrm{~min}$, then trimethylamine ( $33 \mu \mathrm{L}, 24 \mathrm{mg}, 0.24 \mathrm{mmol}$ ) and $\mathrm{AgCF}_{3} \mathrm{SO}_{3}\left(50 \mathrm{mg}, 0.2 \mathrm{mmol}\right.$ ) were added, and the mixture stirred at $70{ }^{\circ} \mathrm{C}$ for $18 \mathrm{~h}$. The mixture was filtered, solvent evaporated to dryness and the residue purified by column chromatography on deactivated alumina with DCM as the eluent. Analytically pure products were obtained after recrystallization from dichloromethane $/ \mathrm{n}$-hexane mixtures.

$\left[\operatorname{Re}(\mathbf{C O})_{3}(\mathbf{b p y})\left(\mathrm{O}_{2} \mathbf{C B z}\right)\right](\mathbf{1 0}) . \mathrm{O}_{2} \mathrm{CBz}=$ benzoate. Yellow solid, yield $59 \%$. ESI ${ }^{+}-\mathrm{MS}$ $(\mathrm{MeOH}): \mathrm{m} / z, 571\left[\operatorname{Re}(\mathrm{CO})_{3}\left(\mathrm{C}_{10} \mathrm{H}_{8} \mathrm{~N}_{2}\right)\left(\mathrm{C}_{7} \mathrm{H}_{5} \mathrm{O}_{2}\right)\right]+\mathrm{Na}^{+},[\mathrm{M}+\mathrm{Na}]^{+}$. IR (solid, $\mathrm{cm}^{-1}$ ); 
vCO: 2012, 1904, 1866. ${ }^{1} \mathrm{H}-\mathrm{NMR}\left(400 \mathrm{MHz}, \mathrm{CD}_{3} \mathrm{CN}\right.$, ppm): 9.08-9.15 (m, $\left.2 \mathrm{H}\right) 8.41$ (d, $J=8.19 \mathrm{~Hz}, 2 \mathrm{H}) 8.20(\mathrm{td}, J=7.92,1.53 \mathrm{~Hz}, 2 \mathrm{H}) 7.58-7.67(\mathrm{~m}, 2 \mathrm{H}) 7.38(\mathrm{dd}, J=8.01,1.28 \mathrm{~Hz}$, 2 H) 7.21-7.29 (m, 1 H) 7.08-7.17 (m, 2 H). UV-Vis (DMF, $\lambda$ nm): 369, 317, 293. Crystals suitable for $\mathrm{X}$-ray diffraction were obtained from layering a solution of tetrahydrofuran with pentane.

$\left[\operatorname{Re}(\mathrm{CO})_{3}(\mathrm{bpy})\left(\mathrm{O}_{2} \mathrm{CPh}\right)\right](\mathbf{1 1}) . \mathrm{O}_{2} \mathrm{CPh}=4$-bromobenzenecarboxylate. Yellow solid, yield 59\%. $\mathrm{ESI}^{+}$-MS $(\mathrm{MeOH}): m / z, 663\left[\mathrm{Re}(\mathrm{CO})_{3}\left(\mathrm{C}_{10} \mathrm{H}_{8} \mathrm{~N}_{2}\right)\left(\mathrm{C}_{8} \mathrm{H}_{6} \mathrm{O}_{2} \mathrm{Br}\right)\right]+\mathrm{Na}^{+},\left[\mathrm{M}+\mathrm{Na}^{+}\right.$. IR (solid, $\mathrm{cm}^{-1}$ ); vCO: 2011,1874. ${ }^{1} \mathrm{H}-\mathrm{NMR}\left(400 \mathrm{MHz}, \mathrm{CD}_{3} \mathrm{CN}, \mathrm{ppm}\right): 8.93$ (dt, $J=4.71$, $0.70 \mathrm{~Hz}, 2 \mathrm{H}) 8.18-8.23(\mathrm{~m}, 2 \mathrm{H}) 8.11-8.17(\mathrm{~m}, 2 \mathrm{H}) 7.54(\mathrm{ddd}, J=7.34,5.62,1.47 \mathrm{~Hz}, 2 \mathrm{H})$ 7.01-7.13 (m, $2 \mathrm{H}) 6.49$ (d, J = 8.56 Hz, $2 \mathrm{H}) 2.97-3.00$ (m, $2 \mathrm{H})$. UV-Vis (DMF, $\lambda \mathrm{nm}$ ): 368 319,293 . Crystals suitable for X-ray diffraction were obtained from layering a solution of tetrahydrofuran with pentane.

$\left[\operatorname{Re}(\mathrm{CO}){ }_{2} \mathbf{N O}(\mathrm{bpy}) \mathrm{BF}_{4}\right]\left(\mathrm{BF}_{4}\right)(\mathbf{1 2})$. Compound $\mathbf{1 0}$ or $\mathbf{1 1}(20-25 \mathrm{mg})$ was dissolved in dry DCM $(20 \mathrm{~mL})$. $\mathrm{NOBF}_{4}$ (1.5 eq.) was added in solid form to the resulting solution. The reaction mixture was stirred for $24 \mathrm{~h}$ at room temperature in dark. A white solid appeared, and then the solvent was decanted from the mixture. The residue was dissolved in DCM and water (1:1). The two phases were separated, and the aqueous phase was washed with DCM. The aqueous phase was concentrated under vacuum. The crude product was crystalized by slow evaporation of a $\mathrm{CHCl}_{3}$ : acetone (1:1) solution to yield crystals of the pure product 12. White solid, yield 55\%. ESI ${ }^{+} \mathrm{MS}(\mathrm{MeOH}): \mathrm{m} / \mathrm{z}, 515.5$ $\left[\operatorname{Re}(\mathrm{CO})_{2}(\mathrm{NO})\left(\mathrm{C}_{10} \mathrm{H}_{8} \mathrm{~N}_{2}\right) \mathrm{BF}_{4}\right]^{+}$. IR (solid, $\left.\mathrm{cm}^{-1}\right) ; \nu \mathrm{CO}: 2127,2069$, vNO: 1820. ${ }^{1} \mathrm{H}$ NMR (400 MHz, $\mathrm{CD}_{3} \mathrm{CN}, \mathrm{ppm}$ ): 9.24-9.27 (dd, 2H), 8.62-8.65 (dd, 2H), 8.45-8.50 (t, 2H), 7.85-7.89 $(\mathrm{td}, 2 \mathrm{H})$. Crystals suitable for X-ray diffraction were obtained by slow evaporation of an acetone solution. Elemental analysis, calcd. for $\mathrm{C}_{12} \mathrm{H}_{8} \mathrm{~B}_{2} \mathrm{~F}_{8} \mathrm{~N}_{3} \mathrm{O}_{3} \mathrm{Re}_{1}$ (\%): C 23.94, H 1.34, N 6.98; found: C 24.43, H 1.35, N 6.69.

$\left[\operatorname{Re}(\mathrm{CO})_{2} \mathrm{NO}(6 \mathrm{Me}-\mathrm{bpy}) \mathrm{Br}\right]\left(\mathrm{BF}_{4}\right)(\mathbf{1 4})$. Prepared according to general procedure for 1-5. 6Me-bpy $=6$-methyl-2,2'-bipyridine. Yellow solid, yield 67\%. ESI ${ }^{+}-\mathrm{MS}(\mathrm{MeOH}): m / z$, $521.6\left[\operatorname{Re}(\mathrm{CO})_{2}(\mathrm{NO})\left(\mathrm{C}_{11} \mathrm{H}_{10} \mathrm{~N}_{2}\right) \mathrm{Br}\right]^{+},[\mathrm{M}]^{+}$. IR (solid, $\left.\mathrm{cm}^{-1}\right) ; v C O: 2114,2050, v N O: 1796$. ${ }^{1} \mathrm{H}-\mathrm{NMR}$ (400 MHz, DMSO-d6, ppm): 3.13 (s, $\left.3 \mathrm{H}\right) 7.98$ (ddd, $J=7.40,5.87,1.16 \mathrm{~Hz}, 1 \mathrm{H}$ ) $8.02-8.07(\mathrm{~m}, 1 \mathrm{H}) 8.47(\mathrm{t}, J=7.95 \mathrm{~Hz}, 1 \mathrm{H}) 8.59(\mathrm{td}, J=7.95,1.47 \mathrm{~Hz}, 1 \mathrm{H}) 8.82(\mathrm{~d}, J=7.58 \mathrm{~Hz}$, $1 \mathrm{H}) 8.94(\mathrm{~d}, J=8.31 \mathrm{~Hz}, 1 \mathrm{H}) 9.50(\mathrm{dd}, J=5.69,0.92 \mathrm{~Hz}, 1 \mathrm{H})$. UV-Vis $\left(\mathrm{CH}_{3} \mathrm{CN}, \lambda \mathrm{nm}\right): 323$, 332. Crystals suitable for $X$-ray diffraction were obtained by vapor diffusion of pentane into a dichloromethane solution.

\subsection{Detection of CO Release Using the Myoglobin Assay}

The photorelease of CO from 1-5 and $\mathbf{1 3}$ was assessed spectrophotometrically by measuring the conversion of deoxymyoglobin $(\mathrm{Mb})$ to carbonmonoxy myoglobin $(\mathrm{MbCO})$ as previously reported [72]. A small aliquot of a freshly prepared solution of the selected complex (in DMSO) was added to $1 \mathrm{~mL}$ of the $\mathrm{Mb}$ solution in phosphate buffer $(0.05 \mathrm{M})$ prepared at $\mathrm{pH}$ 6.8. Final concentrations: $20 \mu \mathrm{M}$ for Re complex and $\mathrm{Mb}$. Mb spectra were recorded after each photoirradiation $(5-10 \mathrm{~min})$ at $375 \mathrm{~nm}$ at $25^{\circ} \mathrm{C}$. The methanol or DMSO content of the solution never exceeded $0.5 \%$. The amount of $\mathrm{MbCO}$ formed was determined by measuring the absorbance at $540 \mathrm{~nm}$ (extinction coefficient $\varepsilon=15.4 \mathrm{M} \mathrm{cm}^{-1}$ ). The $\mathrm{MbCO}$ concentration was plotted over time and directly related to the equivalents of $\mathrm{CO}$ released from the compounds. Control experiments were run under identical conditions but without light or the addition of the metal complexes.

\subsection{Strains and Culture Conditions}

The antimicrobial activity of selected $\left[\operatorname{Re}(\mathrm{CO})_{2}(\mathrm{NO})(\mathrm{N}-\mathrm{N}) \mathrm{X}_{\mathrm{B}} \mathrm{BF}_{4}\right.$ was evaluated against 8 different microorganisms including four Gram-negative bacteria (Enterobacter cloaceae ATCC 3047, Klebsiella pneumoniae ATCC 13803, Acinetobacter baumanii ATCC 19606, Pseudomonas aeruginosa PAO1 NCTC10332), two Gram-positive bacteria (Staphylococcus aureus MRSA43300 (methicillin-resistant) and S. aureus ATCC25923 (methicillin-sensitive)) and two fungi (Candida albicans SC5314) and C. auris (a clinical strain)). All reference strains 
were obtained from the American Type Culture Collection (ATCC) and the National Collection of Type Cultures (NCTC), while the clinical C. auris strain 7 was kindly provided by Dr Aleksandra Barac (University Clinical Center of Serbia) and Prof. Cornelia Lass-Floerl (University of Innsbruck). Prior to each experiment, frozen stocks in $20 \%$ glycerol at $-80^{\circ} \mathrm{C}$ were thawed and inoculated onto solid Yeast-Potato Dextose (YPD) plates (fungi) or Lauria (LA) agar plates (bacteria), and cultured at $37{ }^{\circ} \mathrm{C}$ for $24-48 \mathrm{~h}$.

\subsection{In Vitro Antimicrobial Activity Determination}

Antimicrobial activity was addressed by determining the minimum inhibitory concentration (MIC) of the tested complexes according to the standard broth microdilution assays, recommended by CLSI (the Clinical and Laboratory Standards Institute; M07-A10. CLSI) and EUCAST (European Committee on Antimicrobial Susceptibility Testing; EUCAST antifungal MIC method for yeasts, v 7.3.1). The test strains grown in YPD (fungi) and LA (bacteria) were diluted in RPMI 1640 medium with $2 \%$ glucose (Gibco) and Luria-Bertani broth (Biolife Italiana S.r.l., Milano, Italy) to give the concentration of $1 \times 105 \mathrm{CFU} / \mathrm{mL}$ cells (for fungi) and $5 \times 105 \mathrm{CFU} / \mathrm{mL}$ (for bacteria), respectively. The MIC assay was performed in 96-well microtiter plates (Sarstedt, Germany) by making serial twofold dilutions of the tested substances in appropriate liquid media to give the volume of $100 \mu \mathrm{L}$. The media solution with microorganisms was dispensed to each well to make the final volume of $200 \mu \mathrm{L}$. All complexes were tested in the concentrations range from 100 to $3.13 \mu \mathrm{M}$. After incubation at $37^{\circ} \mathrm{C}$ for $18-24 \mathrm{~h}$ without shaking, the growth of tested microorganisms was determined measuring absorbance at $530 \mathrm{~nm}$ (fungi) and $600 \mathrm{~nm}$ (bacteria) using a Tecan Infinite 200 Pro multiplate reader (Tecan Group Ltd., Männedorf, Switzerland). The negative control (media only) and positive control (only microorganisms) on the same plate were used as references to determine the growth inhibition. Samples with inhibition values above $90 \%$ were classified as active agents.

\section{Conclusions}

In this contribution, we have described an efficient direct nitrosylation of $\alpha$-diimine rhenium tricarbonyl complexes widely applicable to different supporting $\mathrm{N}-\mathrm{N}$ ligands and studied the substitution chemistry of the resulting species. We showed that fac$\left[\operatorname{Re}^{\mathrm{I}}(\mathrm{CO})_{3}(\mathrm{~N}-\mathrm{N}) \mathrm{Br}\right]$ complexes react efficiently with $\mathrm{NOBF}_{4}$ to yield the corresponding dicarbonyl-mononitrosyl species. The resulting compounds are structurally nearly identical higher charge congeners of tricarbonyls. Although the rhenium ion is formally described as having oxidation state +1 , we found that the substitution chemistry of metal ion in $f a c-\left[\operatorname{Re}(\mathrm{CO})_{2}(\mathrm{NO})(\mathrm{N}-\mathrm{N}) \mathrm{X}\right]^{+}$is closer to that of a harder Re acid, probably due to the stronger $\pi$-acceptor properties of $\mathrm{NO}^{+}$as compared to those of $\mathrm{CO}$. In comparison to tricarbonyl species, the higher apparent formal oxidation state of the metal ion in dicarbonyl-mononitrosyl complexes, implies the greater depletion of electron density from the same and, consequently, lower $\pi$-back Re-CO bonding. A fundamental consequence is that $f a c-\left[\operatorname{Re}(\mathrm{CO})_{2}(\mathrm{NO})(\mathrm{N}-\mathrm{N}) \mathrm{X}\right]^{+}$complexes can be photo-activated towards CO release and represent a new class of photoCORMs, releasing ca. 1 equivalent of $\mathrm{CO}$ when photoirradiated with UV light. Preliminary antimicrobial tests of selected $f a c-\left[\operatorname{Re}(\mathrm{CO})_{2}(\mathrm{NO})(\mathrm{N}-\right.$ $\mathrm{N}) \mathrm{XJ}^{+}$complexes indicate that the nitrosyl species behave as the corresponding neutral $f a c-\left[\operatorname{Re}(\mathrm{CO})_{3}(\mathrm{~N}-\mathrm{N}) \mathrm{Br}\right]$ complexes, showing no antimicrobial activity, with minimum inhibitory concentrations (MICs) $>100 \mu \mathrm{M}$.

Supplementary Materials: Figure S1: $400 \mathrm{MHz}{ }^{1} \mathrm{H}-\mathrm{NMR}$ of $\left[\operatorname{Re}(\mathrm{CO})_{2}(\mathrm{NO})(\mathrm{bpy}) \mathrm{Br}\right]\left(\mathrm{BF}_{4}\right)(\mathbf{1})$, Figure S2: $400 \mathrm{MHz}^{1} \mathrm{H}$ NMR spectrum of the $\left[\operatorname{Re}(\mathrm{CO})_{2}(\mathrm{NO})(\mathrm{phen}) \mathrm{Br}_{(\mathrm{BF}}\right)(2)$, Figure S3: $400 \mathrm{MHz}$ ${ }^{1} \mathrm{H}$ NMR spectrum of the $\left[\operatorname{Re}(\mathrm{CO})_{2}(\mathrm{NO})\left(\mathrm{Et}_{2} \mathrm{~N}-\mathrm{bpy}\right) \mathrm{Br}\right]\left(\mathrm{BF}_{4}\right)(3)$, Figure $44: 400 \mathrm{MHz}^{1} \mathrm{H}$ NMR spectrum of $\left[\operatorname{Re}(\mathrm{CO})_{2} \mathrm{NO}(t \mathrm{Bu}-\mathrm{bpy}) \mathrm{Br}\right]\left(\mathrm{BF}_{4}\right)(4)$, Figure $\mathrm{S} 5: 400 \mathrm{MHz}^{1} \mathrm{H}$ NMR spectrum of $\left[\operatorname{Re}(\mathrm{CO})_{2} \mathrm{NO}(\phi-\right.$ phen) $\mathrm{Br}]\left(\mathrm{BF}_{4}\right)(5)$, Figure S6: $400 \mathrm{MHz}^{1} \mathrm{H}$ NMR spectrum of [[Re(CO) $\left.(\mathrm{NO})\left(\mathrm{Et}_{2} \mathrm{~N}-\mathrm{bpy}\right) \mathrm{F}\right]\left(\mathrm{BF}_{4}\right)(7)$, Figure S7: $400 \mathrm{MHz}{ }^{1} \mathrm{H}-\mathrm{NMR}$ of $\left[\operatorname{Re}(\mathrm{CO})_{3}(\mathrm{bpy})\left(\mathrm{O}_{2} \mathrm{CBz}\right)\right](\mathbf{1 0})$, Figure S8: $400 \mathrm{MHz}{ }^{1} \mathrm{H}-\mathrm{NMR}$ of $\left[\operatorname{Re}(\mathrm{CO})_{3}(\mathrm{bpy})\left(\mathrm{O}_{2} \mathrm{CPh}\right)\right](11)$, Figure S9: $400 \mathrm{MHz}^{1} \mathrm{H}_{\mathrm{NMR}}$ spectrum of $\left[\operatorname{Re}(\mathrm{CO})_{2} \mathrm{NO}(\mathrm{bpy}) \mathrm{BF}_{4}\right]\left(\mathrm{BF}_{4}\right)$ (12), Figure S10: $400 \mathrm{MHz}^{1} \mathrm{H}-\mathrm{NMR}$ of $\left[\mathrm{Re}(\mathrm{CO})_{2} \mathrm{NO}(6-\mathrm{Me}-\mathrm{bpy}) \mathrm{Br}\right]\left(\mathrm{BF}_{4}\right)$ (14), Figure S11: $400 \mathrm{MHz}$ 
${ }^{1} \mathrm{H}$ NMR spectrum of $\left[\operatorname{Re}(\mathrm{CO})_{2} \mathrm{NO}(\mathrm{bpy})(\mathrm{Me} 2 \mathrm{~N}-\mathrm{py})\right]\left(\mathrm{BF}_{4}\right)_{2}$ (9), Figure S12: Comparison of the

${ }^{1} \mathrm{H}$ NMR spectra (400 MHz) of (top to bottom) N,N-dimethylpyridin-4-amine (Me2N-py), fac$\left[\operatorname{Re}(\mathrm{CO})_{3}(\mathrm{bpy})(\mathrm{Me} 2 \mathrm{~N}-\mathrm{py})\right]\left(\mathrm{CF}_{3} \mathrm{SO}_{3}\right)(\mathbf{B})$ and $\left[\operatorname{Re}(\mathrm{CO})_{2} \mathrm{NO}(\mathrm{bpy})(\mathrm{Me} 2 \mathrm{~N}-\mathrm{py})\right]\left(\mathrm{BF}_{4}\right)_{2}(\mathbf{9})$, Figure S13: IR spectrum of $\left[\operatorname{Re}(\mathrm{CO})_{2}(\mathrm{NO})(\mathrm{bpy}) \mathrm{Br}\right]\left(\mathrm{BF}_{4}\right)(\mathbf{1})$, Figure $\mathrm{S} 14$ : IR spectrum of $\left[\operatorname{Re}(\mathrm{CO})_{2} \mathrm{NO}(\mathrm{phen}) \mathrm{Br}\right]\left(\mathrm{BF}_{4}\right)$ (2), Figure S15: IR spectrum of $\left[\operatorname{Re}(\mathrm{CO})_{2} \mathrm{NO}\left(\mathrm{Et}_{2} \mathrm{~N}-b p y\right) \mathrm{Br}\right]\left(\mathrm{BF}_{4}\right)(3)$, Figure S16: IR spectrum of $\left[\operatorname{Re}(\mathrm{CO})_{2} \mathrm{NO}(t \mathrm{Bu}-\mathrm{bpy}) \mathrm{Br}\right]\left(\mathrm{BF}_{4}\right)(4)$, Figure S17: IR spectrum of $\left[\operatorname{Re}(\mathrm{CO})_{2} \mathrm{NO}(\phi\right.$-phen $\left.) \mathrm{Br}\right]\left(\mathrm{BF}_{4}\right)(5)$, Figure S18: IR spectrum of $\left[\operatorname{Re}(\mathrm{CO})_{2} \mathrm{NO}(\mathrm{bpy}) \mathrm{F}\right]\left(\mathrm{BF}_{4}\right)(6)$, Figure S19: IR spectrum of $\left[\operatorname{Re}(\mathrm{CO})_{2} \mathrm{NO}\left(\mathrm{Et}_{2} \mathrm{~N}\right.\right.$ bpy)F $]\left(B_{4}\right)(7)$, Figure S20: IR spectrum of $\left[\operatorname{Re}(\mathrm{CO})_{2} \mathrm{NO}(\right.$ bpy $\left.)(\mathrm{Me} 2 \mathrm{~N}-\mathrm{py})\right]\left(\mathrm{BF}_{4}\right)_{2}$ (9), Figure S21: IR spectrum of $\left[\operatorname{Re}(\mathrm{CO})_{3}(\mathrm{bpy})\left(\mathrm{O}_{2} \mathrm{CBz}\right)\right](\mathbf{1 0})$, Figure S22: IR spectrum of $\left[\operatorname{Re}(\mathrm{CO})_{3}(\mathrm{bpy})\left(\mathrm{O}_{2} \mathrm{CPh}\right)\right]$ (11), Figure S23: IR spectrum of $\left[\operatorname{Re}(\mathrm{CO})_{2} \mathrm{NO}(\mathrm{bpy}) \mathrm{BF}_{4}\right]\left(\mathrm{BF}_{4}\right)(\mathbf{1 2})$, Figure S24: IR spectrum of $\left[\operatorname{Re}(\mathrm{CO})_{2} \mathrm{NO}(6-\mathrm{Me}-\mathrm{bpy}) \mathrm{Br}\right]\left(\mathrm{BF}_{4}\right)(\mathbf{1 4})$, Figure S25: UV-Vis spectrum of $\left[\operatorname{Re}(\mathrm{CO})_{2} \mathrm{NO}(\mathrm{bpy}) \mathrm{Br}\right]\left(\mathrm{BF}_{4}\right)(\mathbf{1})$ in acetonitrile, Figure S26: UV-Vis spectrum of $\left[\operatorname{Re}(\mathrm{CO})_{2} \mathrm{NO}(\mathrm{phen}) \mathrm{Br}\right]\left(\mathrm{BF}_{4}\right)(2)$ in DMF, Figure S27: $\mathrm{UV}-\mathrm{Vis}$ spectrum of $\left[\mathrm{Re}(\mathrm{CO})_{2} \mathrm{NO}\left(\mathrm{Et}_{2} \mathrm{~N}-\mathrm{bpy}\right) \mathrm{Br}\right]\left(\mathrm{BF}_{4}\right)(3)$ in acetonitrile, Figure S28: UV-Vis spectrum of $\left[\operatorname{Re}(\mathrm{CO})_{2} \mathrm{NO}(t \mathrm{Bu}-\mathrm{bpy}) \mathrm{Br}\right]\left(\mathrm{BF}_{4}\right)(4)$ in DMF, Figure S29: UV-Vis spectrum of $\left[\operatorname{Re}(\mathrm{CO})_{2} \mathrm{NO}(\phi-\right.$ phen) $\mathrm{Br}]\left(\mathrm{BF}_{4}\right)(5)$ in acetonitrile, Figure S30: UV-Vis spectrum of $\left[\operatorname{Re}(\mathrm{CO})_{2} \mathrm{NO}(6-\mathrm{Me}-\mathrm{bpy}) \mathrm{Br}\right]\left(\mathrm{BF}_{4}\right)(\mathbf{1 4})$ in acetonitrile, Figure S31: UV-Vis spectrum of $\left[\operatorname{Re}(\mathrm{CO})_{2}(\mathrm{NO})\left(\mathrm{Et}_{2} \mathrm{~N}-\mathrm{bpy}\right) \mathrm{F}\right]\left(\mathrm{BF}_{4}\right)(7)$ in acetonitrile, Figure S32: UV-Vis spectrum of $\left[\operatorname{Re}(\mathrm{CO})_{3}(\mathrm{bpy})\left(\mathrm{O}_{2} \mathrm{CBz}\right)\right](\mathbf{1 0})$ in DMF, Figure S33: UV-Vis spectrum of $\left[\operatorname{Re}(\mathrm{CO})_{3}(\mathrm{bpy})\left(\mathrm{O}_{2} \mathrm{CPh}\right)\right](\mathbf{1 1})$ in DMF, Figure S34: UV-Vis spectrum of $\left[\operatorname{Re}(\mathrm{CO})_{2} \mathrm{NO}(\mathrm{bpy}) \mathrm{BF}_{4}\right]\left(\mathrm{BF}_{4}\right)$ (12) in DMF, Figure S35: UV-Vis spectrum of $\left[\operatorname{Re}(\mathrm{CO})_{2} \mathrm{NO}(\right.$ bpy $\left.)\left(\mathrm{Me}_{2} \mathrm{~N}-\mathrm{py}\right)\right]\left(\mathrm{BF}_{4}\right)_{2}(9)$ in acetonitrile, Figure S36: UV-Vis spectrum of $\left[\operatorname{Re}(\mathrm{CO})_{2}(\mathrm{NO})(\mathrm{bpy}) \mathrm{F}\right]\left(\mathrm{BF}_{4}\right)(\mathbf{6})$ in DMF, Figure S37: Emission spectra of selected nitrosyl Re complexes. Top: $\lambda_{\mathrm{ex}}=318$; bottom $\lambda_{\mathrm{ex}}=350$, Table S1: Crystal data and structure refinement for 1, 2, 6-8, 10-14, and fully oxidized complex 14 .

Author Contributions: S.N.S. and I.K. investigation, formal analysis, data curation, methodology, writing-original draft; Y.C., K.S. and S.-C.L. investigation, formal analysis; A.C. crystallography; A.P. conceptualization, investigation, formal analysis, data curation, methodology. F.Z. writing-original draft, review \& editing, conceptualization, supervision, validation, acquisition, resources, project administration. All authors have read and agreed to the published version of the manuscript.

Funding: Financial support from the Fonds de recherche du Centenaire de l’Universite de Fribourg (F.Z. and A.P., Project\# 818), and Swiss National Science Foundation (K.S., Project\# 200021_196967) is gratefully acknowledged.

Data Availability Statement: The data presented in this study are available on request from the corresponding author.

Conflicts of Interest: The authors declare no conflict of interest.

Sample Availability: Not available.

\section{References}

1. Interagency Coordination Group on Antimicrobial Resistance. Meeting the Challenge of Antimicrobial Resistance: From Communication to Collective Action. 2018. Available online: https://www.who.int/antimicrobial-resistance/interagencycoordination-group/IACG_Meeting_challenge_AMR_communication_to_collective_action_270718.pdf?ua=270711 (accessed on 31 January 2021).

2. Dadgostar, P. Antimicrobial Resistance: Implications and Costs. Infect. Drug Resist. 2019, 12, 3903-3910. [CrossRef]

3. Frei, A. Metal Complexes, an Untapped Source of Antibiotic Potential? Antibiotics 2020, 9, 90. [CrossRef] [PubMed]

4. Nasiri Sovari, S.; Zobi, F. Recent Studies on the Antimicrobial Activity of Transition Metal Complexes of Groups 6-12. Chemistry 2020, 2, 418-452. [CrossRef]

5. Frei, A.; Zuegg, J.; Elliott, A.G.; Baker, M.; Braese, S.; Brown, C.; Chen, F.; Dowson, C.G.; Dujardin, G.; Jung, N.; et al. Metal complexes as a promising source for new antibiotics. Chem. Sci. 2020, 11, 2627-2639. [CrossRef] [PubMed]

6. Chen, F.; Moat, J.; McFeely, D.; Clarkson, G.; Hands-Portman, I.J.; Furner-Pardoe, J.P.; Harrison, F.; Dowson, C.G.; Sadler, P.J. Biguanide Iridium(III) Complexes with Potent Antimicrobial Activity. J. Med. Chem. 2018, 61, 7330-7344. [CrossRef] [PubMed]

7. Wenzel, M.; Patra, M.; Senges, C.H.; Ott, I.; Stepanek, J.J.; Pinto, A.; Prochnow, P.; Vuong, C.; Langklotz, S.; Metzler-Nolte, N.; et al. Analysis of the mechanism of action of potent antibacterial hetero-tri-organometallic compounds: A structurally new class of antibiotics. ACS Chem. Biol. 2013, 8, 1442-1450. [CrossRef]

8. Patra, M.; Wenzel, M.; Prochnow, P.; Pierroz, V.; Gasser, G.; Bandow, J.E.; Metzler-Nolte, N. An organometallic structure-activity relationship study reveals the essential role of a $\operatorname{Re}(\mathrm{CO})_{3}$ moiety in the activity against gram-positive pathogens including MRSA. Chem. Sci. 2015, 6, 214-224. [CrossRef] 
9. Siegmund, D.; Lorenz, N.; Gothe, Y.; Spies, C.; Geissler, B.; Prochnow, P.; Nuernberger, P.; Bandow, J.E.; Metzler-Nolte, N. Benzannulated $\operatorname{Re}(\mathrm{I})-\mathrm{NHC}$ complexes: Synthesis, photophysical properties and antimicrobial activity. Dalton Trans. 2017, 46, 15269-15279. [CrossRef]

10. Frei, A.; Amado, M.; Cooper, M.A.; Blaskovich, M.A.T. Light-activated Rhenium Complexes with Dual Mode of Action against Bacteria. Chem. Eur. J. 2019, 26, 2852-2858. [CrossRef] [PubMed]

11. Delasoie, J.; Radakovic, N.; Pavic, A.; Zobi, F. Neovascularization Effects of Carbon Monoxide Releasing Drugs Chemisorbed on Coscinodiscus Diatoms Carriers Characterized by Spectromicroscopy Imaging. Appl. Sci. 2020, 10, 7380. [CrossRef]

12. Santoro, G.; Beltrami, R.; Kottelat, E.; Blacque, O.; Bogdanova, A.Y.; Zobi, F. N-Nitrosamine- $\left.\{\text { cis-Re[CO }]_{2}\right\}^{2+}$ cobalamin conjugates as mixed CO/NO-releasing molecules. Dalton Trans. 2016, 45, 1504-1513. [CrossRef] [PubMed]

13. Prieto, L.; Rossier, J.; Derszniak, K.; Dybas, J.; Oetterli, R.M.; Kottelat, E.; Chlopicki, S.; Zelder, F.; Zobi, F. Modified biovectors for the tuneable activation of anti-platelet carbon monoxide release. Chem. Commun. 2017, 53, 6840-6843. [CrossRef] [PubMed]

14. Suliman, H.B.; Zobi, F.; Piantadosi, C.A. Heme Oxygenase-1/Carbon Monoxide System and Embryonic Stem Cell Differentiation and Maturation into Cardiomyocytes. Antioxid. Redox Signal. 2016, 24, 345-360. [CrossRef]

15. Delasoie, J.; Pavic, A.; Voutier, N.; Vojnovic, S.; Crochet, A.; Nikodinovic-Runic, J.; Zobi, F. Identification of novel potent and non-toxic anticancer, anti-angiogenic and antimetastatic rhenium complexes against colorectal carcinoma. Eur. J. Med. Chem. 2020, 204, 112583. [CrossRef] [PubMed]

16. Delasoie, J.; Schiel, P.; Vojnovic, S.; Nikodinovic-Runic, J.; Zobi, F. Photoactivatable Surface-Functionalized Diatom Microalgae for Colorectal Cancer Targeted Delivery and Enhanced Cytotoxicity of Anticancer Complexes. Pharmaceutics 2020, 12, 480. [CrossRef] [PubMed]

17. Santoro, G.; Zlateva, T.; Ruggi, A.; Quaroni, L.; Zobi, F. Synthesis, characterization and cellular location of cytotoxic constitutional organometallic isomers of rhenium delivered on a cyanocobalmin scaffold. Dalton Trans. 2015, 44, 6999-7008. [CrossRef] [PubMed]

18. Rossier, J.; Hauser, D.; Kottelat, E.; Rothen-Rutishauser, B.; Zobi, F. Organometallic cobalamin anticancer derivatives for targeted prodrug delivery via transcobalamin-mediated uptake. Dalton Trans. 2017, 46, 2159-2164. [CrossRef]

19. Sovari, S.N.; Vojnovic, S.; Bogojevic, S.S.; Crochet, A.; Pavic, A.; Nikodinovic-Runic, J.; Zobi, F. Design, synthesis and in vivo evaluation of 3-arylcoumarin derivatives of rhenium(I) tricarbonyl complexes as potent antibacterial agents against methicillinresistant Staphylococcus aureus (MRSA). Eur. J. Med. Chem. 2020, 205, 112533. [CrossRef]

20. Sovari, S.N.; Radakovic, N.; Roch, P.; Crochet, A.; Pavic, A.; Zobi, F. Combatting AMR: A molecular approach to the discovery of potent and non-toxic rhenium complexes active against C. albicans-MRSA co-infection. ChemRxiv 2021. [CrossRef]

21. Epand, R.M.; Epand, R.F. Lipid domains in bacterial membranes and the action of antimicrobial agents. Biochim. Biophys. Acta 2009, 1788, 289-294. [CrossRef]

22. Epand, R.M.; Epand, R.F. Domains in bacterial membranes and the action of antimicrobial agents. Mol. Biosyst. 2009, 5, 580-587. [CrossRef] [PubMed]

23. Romão, C.C.; Blättler, W.A.; Seixas, J.D.; Bernardes, G.J.L. Developing drug molecules for therapy with carbon monoxide. Chem. Soc. Rev. 2012, 41, 3571-3583. [CrossRef]

24. Schibli, R.; Marti, N.; Maurer, P.; Spingler, B.; Lehaire, M.-L.; Gramlich, V.; Barnes, C.L. Syntheses and Characterization of Dicarbonyl-Nitrosyl Complexes of Technetium(I) and Rhenium(I) in Aqueous Media: Spectroscopic, Structural, and DFT Analyses. Inorg. Chem. 2005, 44, 683-690. [CrossRef] [PubMed]

25. Marti, N.; Spingler, B.; Breher, F.; Schibli, R. Comparative Studies of Substitution Reactions of Rhenium(I) Dicarbonyl-Nitrosyl and Tricarbonyl Complexes in Aqueous Media. Inorg. Chem. 2005, 44, 6082-6091. [CrossRef] [PubMed]

26. Veghini, D.; Berke, H. The Nitrosyl Ligand and the Rhenium-Triflate Bond in Rhenium(I) Complexes. Inorg. Chem. 1996, 35, 4770-4778. [CrossRef]

27. Kurz, P.; Rattat, D.; Angst, D.; Schmalle, H.; Spingler, B.; Alberto, R.; Berke, H.; Beck, W. The chemistry of the fac- $\left[\operatorname{Re}(\mathrm{CO})_{2}(\mathrm{NO})\right]^{2+}$ fragment in aqueous solution. Dalton Trans. 2005, 4, 804-810. [CrossRef]

28. Veghini, D.; Nefedov, S.E.; Schmalle, H.; Berke, H. Synthesis of nitrosyl rhenium(I) complexes bearing bidentate ligands. J. Organomet. Chem. 1996, 526, 117-134. [CrossRef]

29. Casey, C.P.; Andrews, M.A.; McAlister, D.R.; Rinz, J.E. Reduction of coordinated carbon monoxide. Synthesis of neutral metal formyl and hydroxymethyl derivatives of the (cyclopentadienyl)dicarbonyl(nitrosyl)rhenium(1+) cation. J. Am. Chem. Soc. 1980, 102, 1927-1933. [CrossRef]

30. Fischer, E.O.; Strametz, H. Aromatic Complexes of Metals. 105. Cyclopentadienyl-Rhenium-Dicarbonyl-Nitrosyl Cation. Z. Naturforsch. B 1968, 23, 278-279. [CrossRef]

31. Sweet, J.R.; Graham, W.A.G. Stepwise reduction of coordinated carbon monoxide. J. Am. Chem. Soc. 1982, 104, 2811-2815. [CrossRef]

32. Agbossou, F.; O'Connor, E.J.; Garner, C.M.; Méndez, N.Q.; Fernández, J.M.; Patton, A.T.; Ramsden, J.A.; Gladysz, J.A.; O'Connor, J.M.; Tajima, T.; et al. Cyclopentadienyl Rhenium Complexes. Inorg. Synth. 1992, 29, 211-225. [CrossRef]

33. Zobi, F. Ligand Electronic Parameters as a Measure of the Polarization of the CO Bond in $\left[\mathrm{M}(\mathrm{CO})_{\mathrm{x}} \mathrm{L}_{\mathrm{y}}\right]^{(\mathrm{n})} \mathrm{Complexes}$ and of the Relative Stabilization of $\left[\mathrm{M}(\mathrm{CO})_{\mathrm{x}} \mathrm{L}_{\mathrm{y}}\right]^{(\mathrm{n} / \mathrm{n}+1)}$ Species. Inorg. Chem. 2010, 49, 10370-10377. [CrossRef]

34. Zobi, F. Parametrization of the Contribution of Mono- and Bidentate Ligands on the Symmetric CO Stretching Frequency of fac- $\left[\operatorname{Re}(\mathrm{CO})_{3}\right]^{+}$Complexes. Inorg. Chem. 2009, 48, 10845-10855. [CrossRef] [PubMed] 
35. Zobi, F.; Blacque, O.; Steyl, G.; Spingler, B.; Alberto, R. Formation and Reactivity of [(tacn)-N-CO-(ReBr)-Br-III(CO) $)_{2}^{+}$in Water: A Theoretical and Experimental Study. Inorg. Chem. 2009, 48, 4963-4970. [CrossRef] [PubMed]

36. Abram, U.; Hübener, R.; Alberto, R.; Schibli, R. Darstellung und Strukturen von $\left(\mathrm{Et}_{4} \mathrm{~N}\right)_{2}\left[\operatorname{Re}(\mathrm{CO})_{3}(\mathrm{NCS})_{3}\right]$ und $\left(\mathrm{Et}_{4} \mathrm{~N}\right)\left[\operatorname{Re}(\mathrm{CO})_{2} \mathrm{Br}_{4}\right]$. Z. Anorg. Allg. Chem. 1996, 622, 813-818. [CrossRef]

37. Schindler, K.; Crochet, A.; Zobi, F. Aerobically stable and substitutionally labile $\alpha$-diimine rhenium dicarbonyl complexes. RSC Adv. 2021, 11, 7511-7520. [CrossRef]

38. Evans, J.C.; Rinn, H.W.; Kuhn, S.J.; Olah, G.A. The Structures of Nitrogen Oxide-Boron Trifluoride Complexes. Inorg. Chem. 1964, 3, 857-861. [CrossRef]

39. Griffiths, J.E.; Sunder, W.A. Raman spectrum of the hexafluoroaurate(V) anion. Spectrochim. Acta A 1979, 35, 1329-1331. [CrossRef]

40. Millen, D.J. 509. Vibrational spectra of ionic forms of oxides and oxy-acids of nitrogen. Part IV. Raman spectral evidence of ionisation in crystalline nitronium salts. The constitution of solid dinitrogen pentoxide. Note on the spectrum of the perchlorate ion. J. Chem. Soc. 1950, 2606-2612. [CrossRef]

41. Mesmer, R.E.; Palen, K.M.; Baes, C.F. Fluoroborate equilibriums in aqueous solutions. Inorg. Chem. 1973, 12, 89-95. [CrossRef]

42. Hansch, C.; Leo, A.; Taft, R.W. A survey of Hammett substituent constants and resonance and field parameters. Chem. Rev. 1991, 91, 165-195. [CrossRef]

43. Rattat, D.; Verbruggen, A.; Berke, H. Rhenium-Dicarbonyl-Nitrosyl-Komplexe mit Imidazol. Z. Anorg. Allg. Chem. 2006, 632, 1351-1355. [CrossRef]

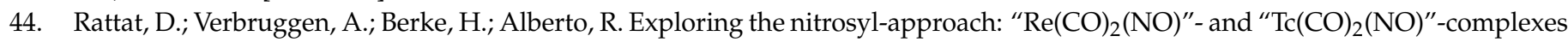
provide new pathways for bioorganometallic chemistry. J. Organomet. Chem. 2004, 689, 4833-4836. [CrossRef]

45. Hayes, T.R.; Bottorff, S.C.; Slocumb, W.S.; Barnes, C.L.; Clark, A.E.; Benny, P.D. Influence of bidentate ligand donor types on the formation and stability in $2+1$ fac- $\left[\mathrm{MI}(\mathrm{CO})_{3}\right]^{+}(\mathrm{M}=\mathrm{Re}, 99 \mathrm{mTc})$ complexes. Dalton Trans. 2017, 46, 1134-1144. [CrossRef] [PubMed]

46. Pitchumony, T.S.; Banevicius, L.; Janzen, N.; Zubieta, J.; Valliant, J.F. Isostructural Nuclear and Luminescent Probes Derived From Stabilized [2 + 1] Rhenium(I)/Technetium(I) Organometallic Complexes. Inorg. Chem. 2013, 52, 13521-13528. [CrossRef] [PubMed]

47. Choualeb, A.; Maccaroni, E.; Blacque, O.; Schmalle, H.W.; Berke, H. Rhenium Nitrosyl Complexes for Hydrogenations and Hydrosilylations. Organometallics 2008, 27, 3474-3481. [CrossRef]

48. Yang, C.S.; Horng, H.C.; Liao, F.L.; Cheng, C.P. Novel coordination mode of boron tetrafluoride anion: Structure of a BF 4 -Capped trirhenium cluster: $\left[\mathrm{NEt}_{4}\right]_{2}^{+}\left[\mathrm{Re}_{3} \mathrm{H}_{2}(\mathrm{CO})_{9} \mathrm{BF}_{4}\right]^{2-}$. J. Chem. Soc. Chem. Commun. 1994, 14, 1637-1638. [CrossRef]

49. Carballo, R.; Castiñeiras, A.; García-Fontán, S.; Losada-González, P.; Abram, U.; Vázquez-López, E.M. Synthesis, structure and reactivity of bromo- and aquatricarbonylrhenium(I) phosphinite and phosphonite derivatives. Polyhedron 2001, 20, $2371-2383$. [CrossRef]

50. Andreev, R.V.; Borodkin, G.I.; Gatilov, Y.V.; Shubin, V.G. First X-ray diffraction study of nitrosonium complexes of nitrogencontaining organic compounds: A complex of 1,10-phenanthroline with $\mathrm{NO}^{+} \mathrm{BF}_{4}{ }^{-}$. Russ. Chem. Bull. Int. Ed. 2001, 50, 2477-2478. [CrossRef]

51. Andreev, R.V.; Borodkin, G.I.; Gatilov, Y.V.; Shubin, V.G. Molecular and crystal structure of 1,10-phenanthroline complex with nitrosonium cation. Russ. J. Org. Chem. 2002, 38, 845-850. [CrossRef]

52. Kubacek, P.; Hoffmann, R. Deformations from octahedral geometry in d4 transition-metal complexes. J. Am. Chem. Soc. 1981, 103, 4320-4332. [CrossRef]

53. Bessette, A.; Nag, S.; Pal, A.K.; Derossi, S.; Hanan, G.S. Neutral Re(I) complexes for anion sensing. Supramol. Chem. 2012, 24, 595-603. [CrossRef]

54. Zobi, F.; Quaroni, L.; Santoro, G.; Zlateva, T.; Blacque, O.; Sarafimov, B.; Schaub, M.C.; Bogdanova, A.Y. Live-Fibroblast IR Imaging of a Cytoprotective PhotoCORM Activated with Visible Light. J. Med. Chem. 2013, 56, 6719-6731. [CrossRef]

55. Zobi, F.; Blacque, O.; Jacobs, R.A.; Schaub, M.C.; Bogdanova, A.Y. 17 e(-) rhenium dicarbonyl CO-releasing molecules on a cobalamin scaffold for biological application. Dalton Trans. 2012, 41, 370-378. [CrossRef]

56. Zobi, F.; Blacque, O. Reactivity of $17 \mathrm{e}(-)$ Complex $\left[\left(\mathrm{ReBr}_{4}\right)-\mathrm{Br}-\mathrm{II}(\mathrm{CO})_{2}\right]^{2-}$ with Bridging Aromatic Ligands. Characterization and CO-Releasing Properties. Dalton Trans. 2011, 40, 4994-5001. [CrossRef] [PubMed]

57. Zobi, F.; Degonda, A.; Schaub, M.C.; Bogdanova, A.Y. CO Releasing Properties and Cytoprotective Effect of cis-trans- [Re$\left.\mathrm{II}(\mathrm{CO})_{2} \mathrm{Br}_{2} \mathrm{~L}_{2}\right]^{(\mathrm{n})}$ Complexes. Inorg. Chem. 2010, 49, 7313-7322. [CrossRef] [PubMed]

58. Pierri, A.E.; Pallaoro, A.; Wu, G.; Ford, P.C. A Luminescent and Biocompatible PhotoCORM. J. Am. Chem. Soc. 2012, 134, 18197-18200. [CrossRef]

59. Chakraborty, I.; Carrington, S.J.; Roseman, G.; Mascharak, P.K. Synthesis, Structures, and CO Release Capacity of a Family of Water-Soluble PhotoCORMs: Assessment of the Biocompatibility and Their Phototoxicity toward Human Breast Cancer Cells. Inorg. Chem. 2017, 56, 1534-1545. [CrossRef]

60. Marker, S.C.; MacMillan, S.N.; Zipfel, W.R.; Li, Z.; Ford, P.C.; Wilson, J.J. Photoactivated in Vitro Anticancer Activity of Rhenium(I) Tricarbonyl Complexes Bearing Water-Soluble Phosphines. Inorg. Chem. 2018, 57, 1311-1331. [CrossRef] 
61. Jiménez-Pulido, S.B.; Illán-Cabeza, N.A.; Hueso-Ureña, F.; Maldonado, C.R.; Sánchez-Sánchez, P.; Fernández-Liencres, M.P.; Fernández-Gómez, M.; Moreno-Carretero, M.N. A combined experimental and DFT investigation on the structure and COreleasing properties of mono and binuclear fac- $\operatorname{Re}(\mathrm{CO})_{3}$ complexes with 5-pyridin-2-ylmethylene-amino uracils. Dalton Trans. 2016, 45, 15142-15154. [CrossRef] [PubMed]

62. Kianfar, E.; Schäfer, C.; Lornejad-Schäfer, M.R.; Portenkirchner, E.; Knör, G. New photo-CORMs: Deeply-coloured biocompatible rhenium complexes for the controlled release of carbon monoxide. Inorg. Chim. Acta 2015, 435, 174-177. [CrossRef]

63. Vaughan, J.G.; Reid, B.L.; Wright, P.J.; Ramchandani, S.; Skelton, B.W.; Raiteri, P.; Muzzioli, S.; Brown, D.H.; Stagni, S.; Massi, M. Photophysical and Photochemical Trends in Tricarbonyl Rhenium(I) N-Heterocyclic Carbene Complexes. Inorg. Chem. 2014, 53, 3629-3641. [CrossRef] [PubMed]

64. Carrington, S.J.; Chakraborty, I.; Bernard, J.M.L.; Mascharak, P.K. A Theranostic Two-Tone Luminescent PhotoCORM Derived from Re(I) and (2-Pyridyl)-benzothiazole: Trackable CO Delivery to Malignant Cells. Inorg. Chem. 2016, 55, 7852-7858. [CrossRef] [PubMed]

65. Chakraborty, I.; Jimenez, J.; Sameera, W.M.C.; Kato, M.; Mascharak, P.K. Luminescent Re(I) Carbonyl Complexes as Trackable PhotoCORMs for CO delivery to Cellular Targets. Inorg. Chem. 2017, 56, 2863-2873. [CrossRef]

66. Takeda, H.; Koike, K.; Morimoto, T.; Inumaru, H.; Ishitani, O. Photochemistry and photocatalysis of rhenium(I) diimine complexes. Adv. Inorg. Chem. 2011, 63, 137-186.

67. Sato, S.; Sekine, A.; Ohashi, Y.; Ishitani, O.; Blanco-Rodríguez, A.M.; Vlček, A.; Unno, T.; Koike, K. Photochemical Ligand Substitution Reactions of fac-[Re(bpy) $\left.(\mathrm{CO})_{3} \mathrm{Cl}\right]$ and Derivatives. Inorg. Chem. 2007, 46, 3531-3540. [CrossRef]

68. Gerbino, D.C.; Hevia, E.; Morales, D.; Clemente, M.E.N.; Pérez, J.; Riera, L.; Riera, V.; Miguel, D. A new reactivity pattern of low-valent transition-metal hydroxo complexes: Straightforward synthesis of hydrosulfido complexes via reaction with carbon disulfide. Chem. Commun. 2003, 3, 328-329. [CrossRef]

69. Sheldrick, G.M. Crystal structure refinement with SHELXL. Acta Cryst. C 2015, 71, 3-8. [CrossRef]

70. Sheldrick, G.M. SHELXT-Integrated space-group and crystal-structure determination. Acta Cryst. A 2015, 71, 3-8. [CrossRef] [PubMed]

71. Skiba, J.; Kowalczyk, A.; Stączek, P.; Bernaś, T.; Trzybiński, D.; Woźniak, K.; Schatzschneider, U.; Czerwieniec, R.; Kowalski, K. Luminescent fac- $\left[\operatorname{Re}(\mathrm{CO})_{3}(\right.$ phen $\left.)\right]$ carboxylato complexes with non-steroidal anti-inflammatory drugs: Synthesis and mechanistic insights into the in vitro anticancer activity of fac- $\left[\operatorname{Re}(\mathrm{CO})_{3}(\right.$ phen)(aspirin)]. New J. Chem. 2019, 43, 573-583. [CrossRef]

72. Motterlini, R.; Clark, J.E.; Foresti, R.; Sarathchandra, P.; Mann, B.E.; Green, C.J. Carbon Monoxide-Releasing Molecules. Circ. Res. 2002, 90, e17-e24. [CrossRef] [PubMed] 